\title{
The MHC Class-I Transactivator NLRC5: Implications to Cancer Immunology and Potential Applications to Cancer Immunotherapy
}

\author{
Akhil Shukla ${ }^{1}$, Maryse Cloutier ${ }^{1}$, Madanraj Appiya Santharam ${ }^{1}$, Sheela Ramanathan ${ }^{1,2}$ \\ and Subburaj Ilangumaran $1,2, *$ (D) \\ 1 Department of Immunology and Cell Biology, Faculty of Medicine and Health Sciences, \\ Université de Sherbrooke, Sherbrooke, QC J1H 5N4, Canada; Akhil.Shukla@USherbrooke.ca (A.S.); \\ maryse.cloutier@usherbrooke.ca (M.C.); Madanraj.Appiya.Santharam@USherbrooke.ca (M.A.S.); \\ Sheela.Ramanathan@USherbrooke.ca (S.R.) \\ 2 CRCHUS, Centre Hospitalier de l'Université de Sherbrooke, Sherbrooke, QC J1H5N4, Canada \\ * Correspondence: Subburaj.Ilangumaran@usherbrooke.ca; Tel.: +1-819-346-1110 (ext. 14834)
}

check for updates

Citation: Shukla, A.; Cloutier, M.; Appiya Santharam, M.; Ramanathan, S.; Ilangumaran, S. The MHC Class-I Transactivator NLRC5: Implications to Cancer Immunology and Potential Applications to Cancer Immunotherapy. Int. J. Mol. Sci. 2021, 22, 1964. https://doi.org/10.3390/ ijms22041964

Academic Editors: Szilvia Benko and Thomas A. Kufer

Received: 12 January 2021

Accepted: 8 February 2021

Published: 17 February 2021

Publisher's Note: MDPI stays neutra with regard to jurisdictional claims in published maps and institutional affiliations.

Copyright: (C) 2021 by the authors. Licensee MDPI, Basel, Switzerland This article is an open access article distributed under the terms and conditions of the Creative Commons Attribution (CC BY) license (https:// creativecommons.org/licenses/by/ $4.0 /)$

\begin{abstract}
The immune system constantly monitors the emergence of cancerous cells and eliminates them. $\mathrm{CD}^{+}$cytotoxic T lymphocytes (CTLs), which kill tumor cells and provide antitumor immunity, select their targets by recognizing tumor antigenic peptides presented by MHC class-I (MHC-I) molecules. Cancer cells circumvent immune surveillance using diverse strategies. A key mechanism of cancer immune evasion is downregulation of MHC-I and key proteins of the antigen processing and presentation machinery (APM). Even though impaired MHC-I expression in cancers is well-known, reversing the MHC-I defects remains the least advanced area of tumor immunology. The discoveries that NLRC5 is the key transcriptional activator of MHC-I and APM genes, and genetic lesions and epigenetic modifications of NLRC5 are the most common cause of MHC-I defects in cancers, have raised the hopes for restoring MHC-I expression. Here, we provide an overview of cancer immunity mediated by CD8 ${ }^{+} \mathrm{T}$ cells and the functions of NLRC5 in MHC-I antigen presentation pathways. We describe the impressive advances made in understanding the regulation of NLRC5 expression, the data supporting the antitumor functions of NLRC5 and a few reports that argue for a pro-tumorigenic role. Finally, we explore the possible avenues of exploiting NLRC5 for cancer immunotherapy.
\end{abstract}

Keywords: NLRC5; MHC-I; cancer immunotherapy

\section{Introduction}

The concept of natural anti-cancer immunity faced decades of skepticism before receiving formal acceptance with the recognition of 'cancer immune evasion' as one of the hallmarks of cancer in the updated treatise of Hanahan and Weinberg [1,2]. On the heels of this recognition came the 'breakthrough of the year' in 2013 from the pioneering works of Tasuku Honjo and Jim Allison on immune checkpoint blockers that launched the era of 'cancer immunotherapy' which has become so successful that the term has entered the mainstream lexicon $[3,4]$. In fact, the foundation for cancer immunology and immunotherapy was laid more than a century ago by William Coley, reporting in 1893 the ability of toxic products from pathogenic streptococci to cause tumor regression despite adverse and even fatal side effects [5]. Even though this work faded into oblivion with the emergence of effective cancer treatments such as radiation therapy and surgery, the ability of bacterial products to boost the body's defense against cancer is still supported by the use of Mycobacterium bovis BCG to treat bladder cancer [6,7]. The idea that immune cells might be involved in the body's fight against cancer, originally suggested by Paul Ehrlich in 1909, was rekindled fifty years later when Lewis Thomas and Frank Macfarlane Burnet put forth the concept of 'immunological surveillance' against newly arising neoplastic 
cells bearing mutations [8]. This concept was experimentally proven by Robert Schreiber and colleagues another forty years later [9]. Meanwhile, understanding of the cellular immune mechanisms paved the way for using the T cell growth factor interleukin-2 (IL-2) to stimulate anti-cancer $\mathrm{CD}^{+}$cytotoxic $\mathrm{T}$ lymphocytes (CTLs) in cancer patients and to expand these CTLs in vitro for the purpose of adoptive cell therapy (ACT) [10,11]. Even though these cancer immunotherapy approaches have been recently shadowed by the tremendous success of immune checkpoint inhibitors (ICI), IL-2 therapy is still being used to treat certain cancers such as renal cell carcinoma [12]. Similarly, the knowhow developed around ACT is applicable to personalized cancer immunotherapy using chimeric antigen receptor bearing $\mathrm{T}$ (CAR-T) cells [13].

Cancer immune surveillance begins with the detection of potentially neoplastic cells by naïve $\mathrm{T}$ lymphocytes via recognition of non-self antigenic epitopes, which are sufficiently different from 'self' epitopes for which T cells were educated to be tolerant during development within the thymus. Ensuing activation of these $\mathrm{T}$ cells, their expansion and killing of target cells that express 'non-self' antigens results in the elimination of potentially neoplastic clones, preventing them from growing into tumors. Essentially, the immune system acts as a 'cell-extrinsic' tumor suppressor analogous to 'cell-intrinsic' tumor suppressors such as p53 to maintain 'self' by eliminating the 'non-self' [14]. Genetic events that facilitate aggressive growth may permit tumors to select neoplastic clones that no longer express the 'immunogenic' tumor antigens in order to overcome cancer immune surveillance. Iteration of these processes enables tumors get past through stages of 'elimination' by the immune system, 'equilibrium' with the immune system and 'escape/evasion' from immune detection - the 'three Es of cancer immunoediting' - first proposed by Robert Schreiber $[9,15]$. At the same time, by studying different murine tumors, Zinkernagel and colleagues demonstrated that activation of antitumor immunity can be quite variable depending on several factors such as the strength of the antigenic epitope, presence or absence of inflammation and the ability to hide within lymph nodes where T cell activation occurs. In addition, certain tumors avoid activating $\mathrm{T}$ cells either by tolerizing the immune system or by resisting immune recognition [16,17]. It is now well established that cancer cells exploit a myriad of cell-intrinsic and cell-extrinsic strategies within the tumor microenvironment and in lymph nodes to prevent both activation of $\mathrm{T}$ cells against the 'non-self' antigens and to dampen the effectiveness of activated antitumor CTLs [18-20]. This knowledge has provided the blueprint to devise diverse strategies aimed at reactivating the immune system and improving its fight against cancer (reviewed in [21]). Current cancer immunotherapy approaches are predominantly aimed at (i) stimulating anti-cancer $\mathrm{T}$ cells (through identification of tumor antigens for personalized vaccines, (ii) inducing immunogenic cell death of tumors (chemotherapeutic agents, killing by oncolytic virus), (iii) achieving efficient activation of antitumor T lymphocytes (via blocking checkpoints, inhibiting immune suppressive cells) and (iv) introducing tumor-reactive CTLs (antitumor CTLs expanded in vitro, engineered CAR-T cells targeting specific tumor antigens), either individually or in different combinations. For all these strategies to be successful the cancer cells must remain susceptible to attack by CTLs. Cancer cells exploit this critical requirement by deploying a simple but effective strategy of hiding from CTLs. This strategy involves downmodulation of major histocompatibility class-I (MHC-I) molecules that are responsible for the presentation of cancer antigenic peptides to CTLs. Even though this phenomenon has been recognized for several decades in diverse cancers, little advance has been made so far in making hidden cancers visible to the immune system [22-25]. A breakthrough in this field came from the discovery of NLRC5 as the key transcriptional activator of genes coding for MHC-I and several key proteins involved antigen processing and the loading of antigenic peptides onto MHC-I molecules [26,27]. Subsequent reports that the expression of NLRC5 is widely compromised in many cancers by deletions, mutations and epigenetic repression highlighted the possibility of exploiting NLRC5 to reverse MHC-I expression defects in cancers [28]. Indeed, NLRC5 has been used in a preclinical model of murine melanoma to restore MHC-I expression, increase tumor immunogenicity and elicit 
protective antitumor immunity [29]. In the following sections, we briefly discuss cancer antigens, the antigen processing pathway that generates MHC-I binding peptides and the various defects of this pathway before describing in detail the biology of NLRC5, its implications in cancer immunogenicity and potential ways of exploiting NLRC 5 to restore MHC-I expression in order to elicit antitumor immunity [26-28].

\section{Cancer Immunogenicity and Tumor Antigenic Peptides}

The ability of the immune system to eliminate 'autologous' (as opposed to possibly allogenic) cancer was first documented in 1943 using serial transplantation of methylcholanthreneinduced sarcomas in inbred C3H mice [30]. It took two decades for direct demonstration of the ability of lymphocytes isolated from immunized rats to cause tumor regression [31]. This was followed by studies documenting in vitro sensitization of immune lymphocytes by tumor cells, expansion of sensitized cells using IL-2 and the ability of the expanded lymphocytes to attack tumors [32,33]. Subsequently, transfection of tumor cells with genes coding for cytokines that promote antigen presentation (discussed later), activate $\mathrm{T}$ cells and APC or induce costimulatory molecules (IFN $\gamma$, IL-2, IL-4, IL-7, GM-CSF) were shown to increase tumor immunogenicity and elicit antitumor immunity [34-37]. Establishment of CTL clones from tumor-infiltrating lymphocytes (TILs) of human tumors, mainly melanoma, revealed that these clones recognized diverse tumor antigens [38-40]. Studies on CTLs reactive to murine tumors induced by viral antigens and CTLs reactive to human tumors established that MHC-I molecules are involved in tumor antigen recognition [41-45]. However, efforts to identify the tumor antigens remained challenging and the initial biochemical fractionation methods were largely unsuccessful [46]. Boon and others applied genetic engineering techniques to successfully identify genes coding for tumor antigens such as MUC-1 and the MAGE (melanoma antigen gene) family proteins [47-50]. Meanwhile, work from Rammensee and others revealed that acid treatment of MHC-I molecules from tumor cells released 8-10 amino acids-long peptides that could activate antitumor CTLs [51-54]. Further works established that these tumor antigenic peptides are derived from mutant proteins (tumor-specific antigens, TSA) or overexpressed embryonic proteins (tumor-associated antigens, TAA) and are presented by MHC-I molecules. CD ${ }^{+}$ T cells, which scan these peptides, recognize any 'deviation from self' and elicit antitumor immunity. Advances in genome sequencing and bioinformatics have now made it possible to detect tumor neoantigens in primary cancers and deduce the immunogenic peptides that can potentially be presented by MHC-I [55-57]. These methods are complemented by proteomic techniques to directly identify MHC-I bound cancer antigenic peptides that arise not only from protein coding sequences but also from non-coding sequences or non-linear coding sequences that are unlikely to be predicted by genome and transcriptome data. The latter include peptides generated from defective ribosomal products (DRiPs), non-coding RNA sequences and fusion peptides created by proteasome catalyzed peptide splicing, and they all could contribute to immune surveillance [58-65]. Prediction methods are being developed for identification of such de novo MHC-I bound peptides in silico [66,67].

\section{Processing and Presentation of Cancer Antigenic Peptides by MHC-I}

The $\mathrm{T}$ cell antigen receptors (TCR) of antitumor $\mathrm{T}$ lymphocytes recognize tumor antigenic peptides presented by MHC molecules [68]. Whereas $\mathrm{CD}^{+} \mathrm{T}$ cells recognize antigenic peptides generated from 'endocytosed' foreign proteins following cleavage by lysosomal proteases and loaded on to MHC class-II (MHC-II) molecules, CD8 ${ }^{+} \mathrm{T}$ cells recognize peptides generated by proteasomes from 'endogenously synthesized' proteins and presented on MHC-I molecules. The cellular machineries involved in the generation of antigenic peptides have been extensively reviewed in the literature [69,70], and only the key steps that are impacted by NLRC5 (discussed later) are briefly discussed here. Whereas the expression of MHC-II is restricted to professional antigen presenting cells (APC) such as dendritic cells (DC), all nucleated cells express MHC-I. Similar to CD4 ${ }^{+} \mathrm{T}$ cells, the initial activation of naïve $\mathrm{CD} 8^{+} \mathrm{T}$ cells requires $\mathrm{TCR}$ recognition of the antigenic 
peptide as well as the engagement of the costimulatory receptor CD28 with its ligands CD80 and CD86, which are upregulated on APCs by inflammatory stimuli [71,72]. This stringent requirement for $\mathrm{CD}^{+} \mathrm{T}$ cell activation by endogenous peptides of cancer cells, which do not express the classical costimulatory ligands, is achieved by antigen 'cross presentation'. In this setting, dead tumor cells that are taken up by APCs, which are also activated by the inflammatory milieu of the tumor microenvironment, are degraded via the antigen processing and presentation machinery (APM) of the MHC-I pathway [73-75]. Antigen cross-presentation also enables provision of the $\mathrm{CD} 4^{+} \mathrm{T}$ cell help, which is needed for efficient activation of naïve $\mathrm{CD} 8^{+} \mathrm{T}$ cells against cancer antigens.

The MHC-I pathway of antigen presentation operates in all nucleated cells under normal conditions as an important mechanism of cellular protein homeostasis that uses proteasomes to recycle aged and defective proteins by cleaving them into peptides and amino acids [76]. In this process, peptides that can bind MHC-I find their way to the cell surface, where they are presented as 'identity badges' to assure the immune system that they belong to 'self' and that there is no pathogen invasion or deviation from 'self' has occurred. In order to generate antigenic peptides, misfolded proteins and those destined for routine turnover are modified by ubiquitin and targeted to the proteasome for degradation [76]. Recent findings show that proteasomes also generate de novo peptides by splicing non-contiguous sequences $[63,64]$. The proteasome is a huge multiprotein complex consisting of seven inner and seven outer rings of core proteins (coded by PSMA1-7 and PSMB1-7, respectively) that form a barrel within which proteolytic cleavage occurs [77,78]. This core proteasome is abutted by a layer of proteasome activator and regulatory subunits. The composition of certain core and regulatory subunits are subject to modulation by IFN $\gamma$, which generates the 'immunoproteasome' by substituting three core proteasomal subunits $(\beta 1, \beta 2, \beta 5)$ and increasing the expression of the proteasome activator PA28 to alter the cleavage specificity and enhance the generation of immunogenic peptides [77]. These peptides are transported across the endoplasmic reticulum (ER) by transport proteins called TAP1 and TAP2 (transporter associated with antigen processing) that form a heterodimeric complex on the ER membrane $[79,80]$. The ER-resident aminopeptidase ERAAP trims the peptide to optimal length to be accommodated by the peptide binding groove of MHC-I formed by the $\alpha 1$ and $\alpha 2$ domains of the MHC-I heavy chain complexed with $\beta 2$ microglobulin $(\beta 2 \mathrm{M})$. The naked MHC-I $\alpha / \beta 2 \mathrm{M}$ is bound by chaperones calreticulin and ERp57 and brought to the TAP by the ER-resident TAP-binding protein (TAPBP, also called Tapasin) to form the peptide loading complex (PLC) [81]. Peptide binding stabilizes MHC-I $\alpha / \beta 2 \mathrm{M}$ complex, and in doing so, facilitates its transport to the cell surface. IFN $\gamma$ upregulates the expression of several components of this pathway including MHC-I, $\beta 2 \mathrm{M}$, TAP transporters and TAPBP, and thereby increases the antigen presentation functions of APCs and somatic cells [82-84]. Enhancing the MHC-I antigen processing pathway clearly underlies the ability of IFN $\gamma$ to improve the antigenicity of poorly immunogenic tumors and enhance their ability to elicit antitumor immunity [84-86].

\section{The Cancer-Immunity Cycle and 'Immune Invisibility' of Cancers}

The development of antitumor immunity leading to the killing of cancer cells can be envisaged as a series of discrete steps as summarized by Chen and Mellman [21] (Figure 1). These steps involve (i) release of tumor antigens through spontaneous death of cancer cells caused by the scarcity of nutrients and oxygen, which is an inevitable consequence of rapid cell proliferation and inadequate vascular supply; (ii) capture of these cell fragments by APCs that migrate to the draining lymph nodes, process antigenic peptides and present them on MHC molecules; (iii) recognition of the MHC-I:tumor antigenic peptide complex and costimulatory ligands by naïve $\mathrm{T}$ lymphocytes, resulting in their activation, clonal expansion and differentiation toward effector CTLs; (iv) migration of effector CTLs via circulation and infiltration into tumors; (v) recognition of cancer cells presenting the same tumor antigenic peptides that activated the naïve $\mathrm{CD} 8^{+} \mathrm{T}$ cells; and (vi) killing of these cancer cells via lytic granules that releases more tumor antigens to stimulate naïve $\mathrm{T}$ 
cells. Reiteration of the above steps in a cyclical manner contributes to tumor elimination. However, cancer cells can modify the cellular and molecular components of the tumor microenvironment that can impact every step of the cancer-immunity cycle. These immune evasion strategies include (i) rendering cancer antigens less immunogenic, (ii) dampening the antigen presenting functions of APCs, (iii) decreasing their stimulatory capacity to naivve $\mathrm{T}$ cells and even rendering them inhibitory, (iv) interference with the infiltration of effector CTLs into tumors, (v) making cancer cells less visible to CTLs or (vi) simply preventing the effector cells from unleashing their killing functions $[18,21,87]$. In fact, advanced stage cancers often deploy several of these inhibitory pathways simultaneously. Advances in the understanding of these inhibitory mechanisms have identified molecules and strategies that can be used to thwart the inhibitory influence of cancers on the activation and antitumor functions of T cells [21]. For instance, blocking the immune checkpoint inhibition caused by CTLA- 4 can boost the initial activation of naïve CD8 T cells, whereas blocking the inhibition mediated by PD-L1 permits cancer cell killing by activated CTLs and can also boost their reactivation $[88,89]$. However, any cancer immunotherapy strategy aimed at activating antitumor $\mathrm{T}$ cells or relieving the inhibitory signals imposed on activated cells is unlikely to be successful if cancer cells deploy immune evasion mechanisms that enable them to remain invisible to CTLs. Cancer cells can achieve such 'immune invisibility' by downmodulating the expression of MHC-I or the components of the APM that generate antigenic peptides essential for stabilizing cell surface MHC-I expression.

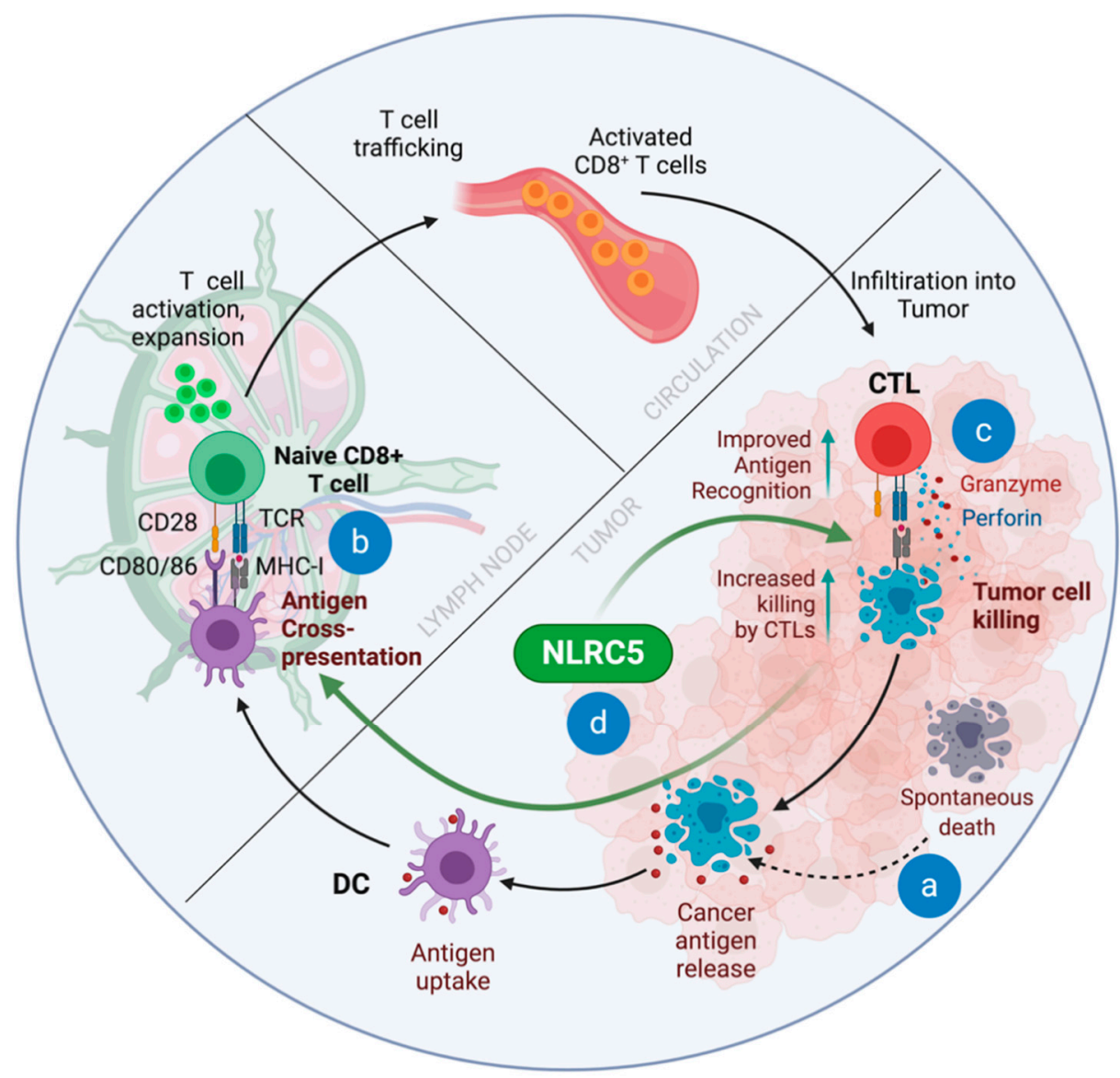

Figure 1. Cancer-Immunity cycle and the points of intervention for NLRC5. Spontaneous death of cancer cells leads to the release of cancer antigens (a), which are taken up by dendritic cells and presented 
via cross-presentation to naïve $\mathrm{CD}^{+} \mathrm{T}$ cells in draining lymph nodes $(\mathbf{b})$. Activated $\mathrm{CD} 8^{+} \mathrm{T}$ cells undergo clonal expansion, differentiate to effector CTLs, enter circulation and traffic to the tumor. Upon recognizing the antigenic peptide on cancer cells, CTLs release their cytotoxic granules to cause tumor cell killing (c). Release of more tumor antigens and their cross-presentation to additional naïve $\mathrm{CD}^{+} \mathrm{T}$ cells results in reiteration of this cycle leading to tumor elimination. However, this process can be impaired at multiple nodes of this cancer immunity cycle including immune checkpoint inhibition at CTL-mediated killing and naïve T cell activation. Tumors that downmodulate MHCI escape immune detection and killing, thereby dampening the development and execution of antitumor immunity. As genetic lesions and epigenetic modifications of the NLRC5 gene are the most common causes of MHC-I downregulation in cancers, restoration of NLRC5 (d) will restore tumor immunogenicity, leading to efficient killing of tumor cells and potentiation of antitumor immunity (thick green arrows).

\section{Defective MHC-I Expression in Cancers}

Human cancers downregulate MHC-I molecules, known as human leukocyte antigens (HLA), to avoid destruction by antitumor CTLs [22,90,91]. The HLA class-I molecules include the classical (class-Ia) HLA-A, B and C molecules, which are highly polymorphic and ubiquitously expressed, and the non-classical (class-Ib) HLA-E, F, G, MICA (MHC-I chain related protein $\mathrm{A}$ ) and $\mathrm{MICB}$, which are less polymorphic and restricted in expression [92-95]. During cancer growth, cells with varying degrees of HLA-Ia expression defects may arise. These defects that occur in both primary and metastatic cancers may range from loss of one or more HLA-Ia gene alleles, loss of one or more HLA-I loci, loss of an HLA haplotype (an entire set of A, B, C loci) or total loss of HLA-I $[22,96,97]$. These defects have also been studied using mouse models to gain insight into the underlying mechanisms $[23,86]$. Whereas the selective loss of alleles and loci could arise from mutations and deletions of specific MHC-I gene loci, the total loss of MHC-I most likely arises from defective expression of $\beta 2 \mathrm{M}$ or any of the key components of the MHC-I antigen presentation pathway required to generate antigenic peptides and facilitate their binding to MHC [22,98-100]. Indeed, defective expression of TAP and TAPBP has been implicated in the loss of HLA-I expression in cancers, cancer cell lines and mouse models [101-103]. Defective MHC-I expression in cancers may also arise from impaired interferon signaling pathways $[104,105]$. The MHC-I defects have been shown to correlate with high tumor grading, disease progression, reduced survival and failure of CTL-based immunotherapies $[91,103,106,107]$. Notably, in melanoma patients undergoing immunotherapy, all regressing metastatic lesions expressed residual MHC-I while progressing metastases did not $[107,108]$. Efforts to understand the underlying mechanisms revealed that the MHC-I expression defects can arise from 'soft' reversible or 'hard' irreversible lesions [23,25,109,110]. Hard lesions arising from gene loss or structural mutations are less common than soft lesions arising from epigenetic modifications that impair gene expression. The latter is exemplified by restoration of MHC-I expression by IFN $\gamma$ or drugs such as 5-azacytidine (5-Aza) and trichostatin-A that inhibit DNA methylation and histone deacetylation, respectively [84,111-116]. Interestingly, 5-Aza restored IFN $\gamma$-induced upregulation of MHC-I in a melanoma cell line [104]. MHC-I expression has also been associated with demethylation of TAP1 and TAP2 genes, suggesting that IFN $\gamma$ functions at least partly as an epigenetic modifier of APM genes [117]. This idea is also supported by the enrichment of IFN $\gamma$-induced genes and MHC-I antigen presentation pathway genes among those induced by 5-Aza in breast, ovarian and colorectal cancer cell lines [118].

MHC-I expression may also be regulated at post-transcriptional level. For instance, the $\mathrm{K} 3$ family of ubiquitin ligases encoded by Kaposi's sarcoma-associated herpes virus promote K63-linked polyubiquitination of MHC-I, resulting in its internalization and lysosomal degradation, as an immune evasion strategy [119-124]. The cellular orthologs of K3 family are the MARCH (Membrane-associated RING-CH-type finger) family E3 ligases, which mediate ubiquitination and lysosomal degradation of MHC-II molecules [125]. A recent study implicates MARCH-9 in the regulation of MHC-I molecules [126]. In colon 
and pancreatic cancer cells, oncogenic RAS signaling promotes autophagy that results in lysosomal degradation of MHC-I, leading to their immune escape [127-129].

\section{Loss of NLRC5 Expression Frequently Underlies Reduced MHC-I Expression in Cancers}

A breakthrough in understanding the regulation of MHC-I genes and their defective expression in cancers came from the work of Kobayashi group on the nucleotide-binding leucine-rich repeat-containing receptor (NLR) family protein NLRC5 [130]. The NLR family proteins function as innate immune receptors that recognize pathogen- and dangerassociated molecular patterns in the cytosol [131,132]. Activation of certain NLR proteins (NOD1, NOD2) leads to activation of the NF-KB pathway, whereas others (NLRP1b, NLRP3, NLRC4) assemble into inflammasomes and activate caspase- 1 to promote maturation and release of inflammatory cytokines IL-1 $\beta$ and IL-18 [131,132]. Another well-characterized NLR protein is NLRA, which does not activate NF- $\mathrm{kB}$ or inflammasome, but has been known since the early 90s as the MHC class-II transactivator (CIITA) due to its crucial requirement as a transcriptional coactivator of MHC-II genes [133,134]. Early studies using overexpression and knockdown approaches in cell lines implicated NLRC5 in negatively regulating inflammatory pathways by attenuating NF- $\kappa B$ activation and in lessening antiviral responses by inhibiting type-I IFN production [135-138]. However, several groups have reported that bone marrow-derived dendritic cells and macrophages established from Nlrc5 $5^{-/-}$mice failed to show any difference in NF-kB-dependent pro-inflammatory cytokine gene expression or protein production following exposure to LPS, viruses or bacteria [139-142]. Curiously, one of these studies showed that Nlrc5 ${ }^{-/-}$primary embryonic fibroblasts did show enhanced NF- $\mathrm{KB}$ signaling and pro-inflammatory cytokine secretion [142]. More recently, the Ferrero laboratory has recently shown that NLRC5-mediated attenuation of NF- $\mathrm{kB}$ signaling in macrophages is crucial to attenuate chronic inflammation of the gastric mucosa caused by Helicobacter pyroli [143]. It has been suggested that NLRC5 is an unlikely regulator of pro-inflammatory NF- $\mathrm{KB}$ signaling [144] although such a role can be envisaged in certain cells that may not harbor other robust control mechanisms or exhausted them. It is also noteworthy that NLRC5 may also contribute to inflammasome activation via co-operating with NLRP3 [145-147].

Intrigued by nuclear localization of NLRC5 and its structural similarity to CIITA, the Kobayashi group investigated modulation of gene expression by NLRC5 [130]. This seminal study revealed that NLRC5 upregulated a limited set of genes, notably those coding for MHC-I, $\beta 2 \mathrm{M}$, APM (TAP1) and immunoproteasome components (LMP2/PSMB9/ $\beta 1 \mathrm{i}$, LMP7/PSMB8/ $\beta 5$ i). This study also showed that NLRC5 is strongly induced by IFN $\gamma$ and that NLRC5 targeting siRNA attenuated IFN $\gamma$-mediated upregulation of MHC-I, indicating that NLRC5 is a crucial mediator of IFN $\gamma$-stimulated upregulation of the MHC-I antigen presentation pathway. Studies on NLRC5 deficient mice, generated by several laboratories, revealed that NLRC5 is critical for basal and IFN $\gamma$-induced expression of MHC-I and APM genes, but is dispensable for the regulation of pathogen-induced inflammatory cytokines, although some studies reported increased TLR-stimulated inflammatory cytokine production $[139,140,142,146,148,149]$. Thus, in analogy to CIITA, NLRC5 is recognized as MHC class-I transactivator (CITA) [27]. Subsequent studies from the Kobayashi laboratory revealed that NLRC5 is inactivated in diverse cancers by a variety of genetic mechanisms including promoter methylation, copy number loss and mutations, and that the loss of NLRC5 expression correlates with reduced CTL activation and patient survival in several cancers including melanoma, bladder and cervical cancers [28]. This study also showed that the demethylating agent 5-Aza increased NLRC5 gene expression, suggesting that the earlier findings on the effects 5-Aza in restoring MHC-I expression occurred at least partly via derepressing NLRC5.

\section{Structure and Transcriptional Coactivator Function of NLRC5}

NLRC5 is the largest member of the NLR protein family with a size of more than $204 \mathrm{kDa}$ [150] (Figure 2A). The NLRC5 gene is highly conserved in vertebrates, with 
mouse and human NLRC5 containing 1915 and 1866 amino acids, respectively [135,151]. The NLR proteins display a tripartite domain architecture with a variable N-terminal protein interaction domain, a conserved central nucleotide-binding oligomerization domain (NBD/NOD) called NACHT (named after NAIP, CIITA, HET-E, and TP-1 proteins) and leucine-rich repeats (LRR) in the C-terminus that sense molecular patterns and vary in number in different NLR proteins [132,152]. Both NLRA/CIITA and NLRC5/CITA possess the central NACHT domain but vary in their $\mathrm{N}$ - and C-termini. Whereas CIITA harbors a caspase recruitment domain (CARD) and a trans-activator domain, the $\mathrm{N}$-terminus of NLRC5 carries an atypical CARD domain [153]. CIITA carries four LRRs whereas NLRC5 harbors twenty LRRs although shorter isoforms containing fewer LRRs have been reported $[27,137]$.

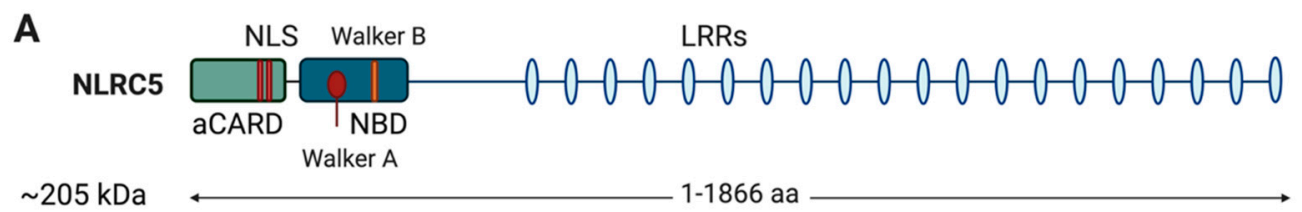

B

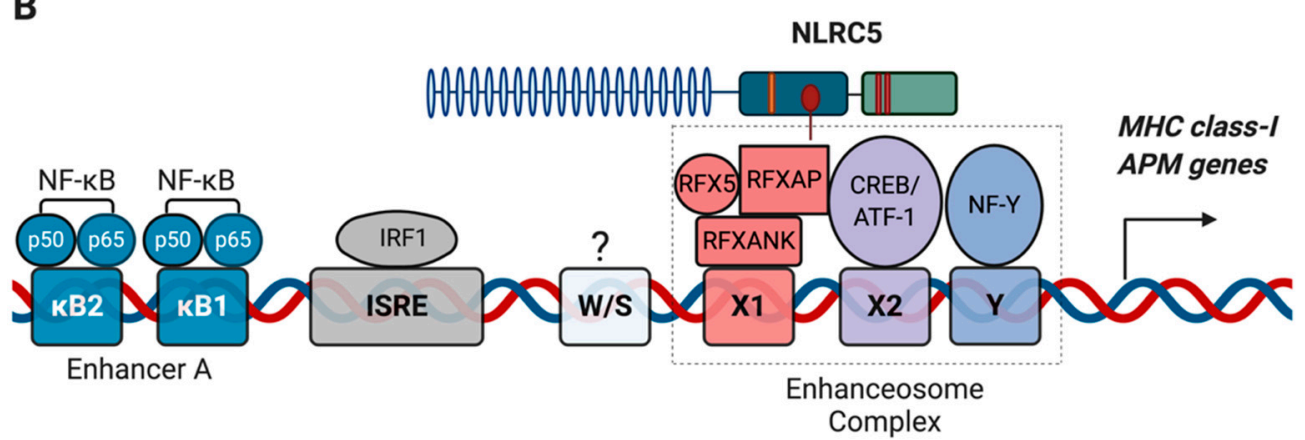

C

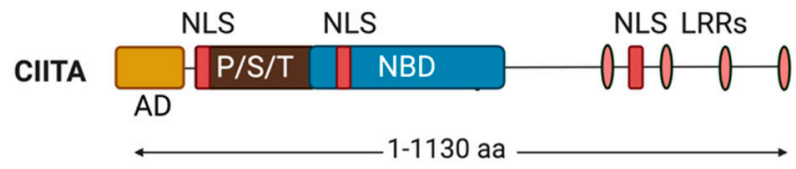

D

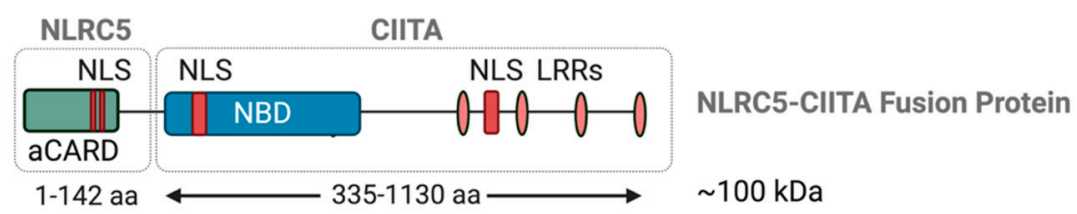

Figure 2. Structure and transactivation functions of NLRC5. (A) NLRC5 (1866 aa) displays a tripartite structure consisting of (i) an atypical CARD (aCARD; 1-139 aa) domain with a helix extending to residue 161 and a bipartite Nuclear Localization Sequence (NLS; 121-122, 132-134 aa), (ii) a Nuclear Binding Domain (NBD; 197-369 aa) that harbors Walker A and Walker B motifs (228-235, 303-313 aa) and (iii) twenty Leucine Rich Repeats (LRRs) (589-1866 aa). (B) NLRC5 transactivates MHC-I and APM genes via the SXY module. NLRC5 lacks a DNA binding domain and thus interacts through the enhanceosome complex formed by the transcription factors (RFX proteins, CREB/ATF1, NF-Y) bound to $\mathrm{X} 1, \mathrm{X} 2$ and $\mathrm{Y}$ box motifs. RFX5 acts as a key mediator for binding of NLRC5 with the promoter. The LRRs of NLRC5 are compressed for clarity. The MHC-I promoters also harbor an interferon stimulated responsive element (ISRE) and $\mathrm{\kappa B}$ consensus sites that bind IRF1 and NF- $\mathrm{KB}$, respectively. (C) Structure of CIITA (NLRA; 1130 aa). CIITA has an acidic activation domain (AD) (1-125 aa), three nuclear localization sequences (141-159, 405-414, 955-959 aa), a P/S/T domain (Pro/Ser/Thr; 126322 aa), an NBD (336-702 aa) and four LRRs (930-1130 aa). (D) The Kufer laboratory has engineered an NLRC5-CIITA fusion protein containing the aCARD domain of NLRC5 and NBD and LRRs of CIITA. This fusion protein transactivates MHC-I genes as efficiently as the full length NLRC5. 
Unlike most NLR proteins that operate within the cytosol, the transactivation function of CIITA and NLRC5 requires them to shuttle between the cytosol and the nucleus $[27,130]$. The NBD/NACHT domain consists of Walker A and Walker B motifs that bind and hydrolyze nucleotide triphosphate (GTP/ATP), respectively. A nuclear localization signal (NLS) is located upstream of the NACHT domain. Both Walker A motif and NLS of NLRC5 are critical for nuclear localization, promoter binding and MHC-I gene induction $[130,154,155]$. The promoters of MHC-I and APM genes share the cis-regulatory elements of the MHC-II gene promoter namely, the W/S, X1, X2 \& Y boxes (collectively referred to as the SXY regulatory module) that recruit DNA binding factors $[156,157]$ (Figure 2B). The $\mathrm{X} 1$ box binds to a heteromeric DNA binding complex RFX composed of RFX5, RFX-associated protein (RFXAP), and RFX-associated ankyrin-containing protein (RFXANK/RFXB), whereas the $\mathrm{X} 2$ box is bound by cAMP-responsive element binding protein (CREB1) or the activating transcription factor 1 (ATF1), and the $Y$ box binds to the Nuclear Factor-Y (NF-Y) composed of NF-YA, NF-YB and NF-YC subunits [157]. These factors are ubiquitously expressed and constitutively bound to the promoters of MHC genes and constitute the 'transcriptional enhanceosome'. Steimle et al., discovered that CIITA (NLRA) is the essential co-activator of the MHC-II enhanceosome but is dispensable for MHC-I gene expression [133]. The work of Meissner et al., showed that co-activation of the MHC-I promoter is mediated by NLRC5, which is recognized as the bona fide CITA [130]. Both CIITA and CITA do not bind DNA but interact with the enhanceosome factors to activate MHC gene transcription. Despite the conserved nature of the SXY module and the transcription factors that bind to these motifs, NLRC 5 does not influence MHC-II expression $[130,158]$. By comparing the genes regulated by NLRC5 and CIITA in cells derived from mice lacking NLRC5, CIITA or both, Ludigs et al. showed that these two related transcriptional coactivators activate distinct sets of genes and attributed this specificity to significant sequence divergence within the consensus SXY module [158]. Specifically, in contrast to the tight spacing constraints between $\mathrm{S}, \mathrm{X}$ and $\mathrm{Y}$ motifs within the CIITA binding sites, the X-Y spacing is more relaxed within the NLRC5-binding sites. More importantly, the consensus S motif sequence of the NLRC5 binding sites was found to be quite distinct from that of CIITA binding sites and play a key role in determining the specificity. However, increasing the abundance of CIITA can lead to promiscuous activation of MHC-I promoter constructs [158].

Similar to MHC-II genes, MHC-I genes are induced by IFN $\gamma$, and CIITA can promote IFN $\gamma$-induced MHC-I expression [159,160]. This is achieved through the IFN $\gamma$-induced interferon regulatory factor-1 (IRF1) binding to the IFN-stimulated response element (ISRE) $[159,161]$. NLRC5, in addition to activating the enhanceosome, also co-operates with IRF1 [26]. The MHC-I promoters may also harbor one or two NF- $\mathrm{kB}$ binding motifs within the enhancer A site that account for the TNF $\alpha$-mediated MHC-I expression $[162,163]$. Some MHC-I gene promoters carry binding sites for additional transcription factors such as Sp-1 [162,164]. Even though the promoters of most of MHC-I, $\beta 2 \mathrm{M}$ and APM (TAP1, PSMB9/LMP2) genes share the SXY module, there is considerable variation in the presence and number of the auxiliary ISRE and enhancer A elements [157]. These additional regulatory elements, co-operating with CIITA may account for the residual MHC-I expression observed in NLRC5 deficient mice. CIITA promotes MHC-II expression by recruiting various chromatin modifying factors histone acetyltransferases, deacetylases and methyltransferases [165]. ChIP assays on NLRC5-deficient hematopoietic cells indicate that NLRC5 relieves the silencing effect of histone methylation (H3K27me3) at MHC-I promoters [140].

\section{Role of NLRC5 in MHC-I Expression, CD8 ${ }^{+} \mathrm{T}$ Cell Development and Functions}

Even though different studies reported highly variable levels of NLRC5 expression in different tissues, all studies show elevated expression in hematopoietic cells and tissues $[135,136,149,151,154]$. CD8 ${ }^{+}$and $\mathrm{CD}^{+} \mathrm{T}$ lymphocytes in mouse and human show constitutively high NLRC5 expression. B lymphocytes, natural killer (NK) cells and NK-T cells also show high NLRC5 expression, whereas macrophages and dendritic cells show 
intermediate levels. Genetic ablation of the Nlrc5 gene in mice results in drastic reduction of surface MHC-I protein expression in lymphoid cells (thymic and peripheral $\mathrm{CD}^{+}$and $\mathrm{CD}^{+} \mathrm{T}$ lymphocytes, NK, NKT and $\gamma \delta \mathrm{T}$ cells), intermediate decrease in B cells and a mild reduction in dendritic cells and macrophages $[140,149,166,167]$. Unlike CIITA deficiency, which results in impaired maturation of double positive thymocytes to CD4 single positive T cells, Nlrc5 gene deletion does not affect the generation of mature CD8 single positive cells despite causing notable reduction in MHC-I protein expression in hematopoietic cells $[146,149,168,169]$. As the complete loss of MHC-I abolishes CD8 ${ }^{+} \mathrm{T}$ cell maturation, the lack of appreciable impact of NLRC 5 deficiency on $\mathrm{CD} 8^{+} \mathrm{T}$ cell development could be explained by the high constitutive expression of MHC-I in thymic epithelial cells and its moderate reduction by NLRC 5 deficiency $[158,170]$. It is noteworthy that skin epithelial cells display only moderate levels of constitutive MHC-I expression despite very high levels of Nlrc5 transcripts, suggesting additional regulation of MHC-I gene transactivation [170].

Whereas constitutive MHC-I expression is dependent on occupation of the SXY module by transcription factors and their co-activation by NLRC5 [158], induced upregulation of MHC-I expression is mediated by the synergistic effect of activating additional cisregulatory elements (ISRE and enhancer A) and the induction of NLRC5 itself. IFN $\gamma$ strongly induces the expression of NLRC5 in both hematopoietic and non-hematopoietic cells, whereas type-I IFNs (IFN-I: IFN $\alpha$, IFN $\beta$ ) cause moderate upregulation. Agents that induce IFN-I such as virus infection and TLR ligands such as polyinosinic-polycytidylic acid (poly I:C; TLR3), lipopolysaccharide (LPS; TLR4) and CpG oligonucleotides (TLR9) also cause moderate upregulation of NLRC5 [136,142,149,151,154]. IFN stimulation results in the formation of STAT1 homodimers that binds the gamma activated sequence (GAS) at IRF1 and NLRC5 gene promoters to induce their expression, resulting in their synergy at the MHC-I gene promoters [171]. IFN and STAT1 activation are also implicated in the upregulation of NLRC5 in activated $\mathrm{CD}^{+}$and $\mathrm{CD} 8^{+} \mathrm{T}$ lymphocytes [149]. During viral infection, IFN-I protects activated $\mathrm{CD} 8^{+} \mathrm{T}$ cells from NK cell-mediated killing by upregulating classical and non-classical MHC-I molecules [172]. The Guarda laboratory showed that NLRC5 is the crucial mediator of IFN-I mediated upregulation of MHC-I in CD4 ${ }^{+}$and $\mathrm{CD}^{+} \mathrm{T}$ cells during inflammatory conditions and viral infection and this upregulation is crucial to inhibit their killing by NK cells [173].

The impact of NLRC 5 on the ability of APCs to activate $\mathrm{CD} 8^{+} \mathrm{T}$ cells has been investigated in several studies using NLRC5-deficient mice. Bone marrow-derived macrophages (BMDM) from NLRC5-deficient mice pulsed with the SINFEKKL peptide induced proliferation of OT-I TCR transgenic CD8 ${ }^{+} \mathrm{T}$ cells as efficiently as control BMDCs [149]. However, NLRC5 deficient $\mathrm{T}$ cells served as poor CTL targets for OT-I cells in vitro. In contrast to BMDCs, NLRC5-deficient B cells pulsed with the same peptide were less efficient than wildtype B cells in inducing proliferation of OT-1 cells [148]. Even though this difference could be attributed to lower levels of MHC-I (H-2K) in resting B cells than in LPS-stimulated BMDM, another study reported that LPS-stimulated bone-marrow-derived dendritic cells (BMDC) from NLRC5-deficient mice were also less efficient in a similar experimental setting [146]. Whether the observed differences in the requirement for NLRC5 to present exogenously added peptide reflects the amount of surface MHC-I in the different cell types needs to be determined under controlled conditions using cells derived from same mice. Nevertheless, as NLRC5 regulates not only MHC-I genes but also APM genes, whether NLRC5 is needed for the physiologically relevant $\mathrm{CD} 8^{+} \mathrm{T}$ cell activation mediated by endogenously synthesized and cross-presented antigens has been addressed in vitro and in vivo. The Guarda laboratory expressed GFP-tagged SIINFEKL in BMDC and found no appreciable difference in OT-I cell activation despite reduced presentation of endogenous peptide [174]. NLRC5 deficiency reduced the number of IFN $\gamma$-producing $\mathrm{CD} 8^{+} \mathrm{T}$ cell numbers in the spleen and liver following intravenous infection with Listeria monocytogenes, accompanied by increased bacterial load [146,148]. Kanneganti and colleagues also observed reduced antigen-specific $\mathrm{CD} 8^{+} \mathrm{T}$ cell numbers in the lungs and draining lymph nodes of NLRC5-deficient mice following intranasal infection with influenza virus that was 
accompanied by increased viral titers, although the mice eventually recovered [166]. Even though the reduction in $\mathrm{T}$ cell numbers in these in vivo studies are generally attributed to impaired $\mathrm{CD} 8^{+} \mathrm{T}$ cell activation, these results could also be explained, at least partly, by the NK-cell mediated elimination of activated T cells as total NLRC5 knockout mice was used in these studies [173]. Sun et al. reported that mice lacking NLRC5 in CD11 ${ }^{+}$DCs showed reduced $\mathrm{CD}^{+} \mathrm{T}$ cell numbers and altered immunodominance hierarchy in small intestinal lamina propria of NLRC5-deficient mice following oral Rota virus infection, indicating that NLRC5 impacts the antigen presentation functions of APCs [167]. Clearly further studies are needed to distinguish the requirement of NLRC5 in APCs for priming and cross-priming of naïve $\mathrm{CD} 8^{+} \mathrm{T}$ cells in the presence or absence of co-stimulatory signals, in activated $\mathrm{CD} 8^{+} \mathrm{T}$ cells for their survival, and in target cells such as cancer cells and virus-infected cells for rendering them susceptible to effector $\mathrm{CD}^{+} \mathrm{T}$ cells as this could facilitate cross-priming (Figure 1).

\section{Induction of Butyrophilins by NLRC5 and $\gamma \delta$ T Cell Activation}

A recent report from the Guarda laboratory has implicated NLRC5 in activating $\gamma \delta \mathrm{T}$ cells via inducing the expression of butyrophilin (BTN) family proteins BTN3A13 [175]. $\gamma \delta$ T cells express TCR with limited diversity that recognize self-MHC proteins in an innate-like fashion independently of their peptide cargo. These cells also recognize pathogen-encoded molecules and altered self-encoded molecules associated with disease states [176]. The human $\mathrm{V} \gamma 9 \mathrm{~V} \delta 2 \mathrm{TCR}$ bearing cells recognize conformational changes in the extracellular domain of BTN3A1 resulting from the binding of low molecular mass phospho-antigens (pAg) to the intracellular B30.2 domain conserved among BTN and BTN-like proteins $[177,178]$. The pAgs are generated by deregulated mevalonate pathway in pathogen-infected and transformed mammalian cells. The BTN family is closely related to the B7 family of costimulatory proteins and are implicated in maintaining immune homeostasis by modulating $\mathrm{T}$ cell activity [178]. The human BTN family genes reside within the MHC locus on chromosome 6 and Btn2a2 is regulated by CIITA via the SXY module [179]. Guarda and colleagues showed that human BTN3A genes (BTN3A1, BTN3A2, $B T N 3 A 3)$ also harbor the SXY module, and their expression positively correlates with NLRC5 [175]. NLRC5 was shown to bind the promoter region of BTN3A and induce its expression, suggesting a potential role for NLRC5 in immune homeostasis. Even though crosslinking BTN3A on T cells delivers an inhibitory signal, the impact of high expression of BTN3A in cancer cells on antitumor immunity is not yet clear [178]. Dang et al., showed that forced expression of NLRC5 in the human Burkitt lymphoma cell line Raji upregulated BTN3A expression and rendered them susceptible to killing by $\gamma \delta \mathrm{T}$ cells [175].

\section{Regulation of NLRC5 Expression}

As the NLRC5-mediated regulation of inflammation and MHC-I expression has potential application in cancer immunotherapy (discussed later), it is important to understand the underlying mechanisms regulating its expression. NLRC 5 is strongly induced by IFN $\gamma$ in different cell types, and to a lesser extent by type-I IFN [27] (Figure 3). In thymic epithelial cells, elevated basal NLRC5 expression is dependent on IFN $\lambda$ [170]. Different studies have reported highly variable basal NLRC5 expression in different tissues [135,136,149,151,154], but the underlying regulatory mechanisms have not been thoroughly studied. The promoter region of NLRC5 (corresponding to position -1 to -1673 relative to the first exon), cloned from human genomic DNA, showed potent inducibility by IFN $\gamma$ in reporter assays in HeLa S3 cells but was not induced by LPS [151]. On the other hand, LPS was a strong inducer of NLRC5 gene expression in murine primary macrophages and cell lines [135]. Kuenzel et al., predicted two STAT1 binding sites at -1336 and -452 relative to transcription stat site (TSS), with the distal site overlapping with a predicted NF- $\mathrm{kB}$ consensus sequence [151]. (Figure 3 ) These reports suggest variable chromatin accessibility of the NLRC 5 promoter in different cell types and additional modulation by transcription factors. Indeed, epigenetic regulation by chromatin remodeling appears to be a key mecha- 
nism underlying differential NLRC5 expression. Hypermethylation of the NLRC5 gene promoter was reported to be the most common epigenetic mechanism associated with reduced MHC-I expression in human cancers and cell lines that could be reversed by 5-Aza treatment [28].

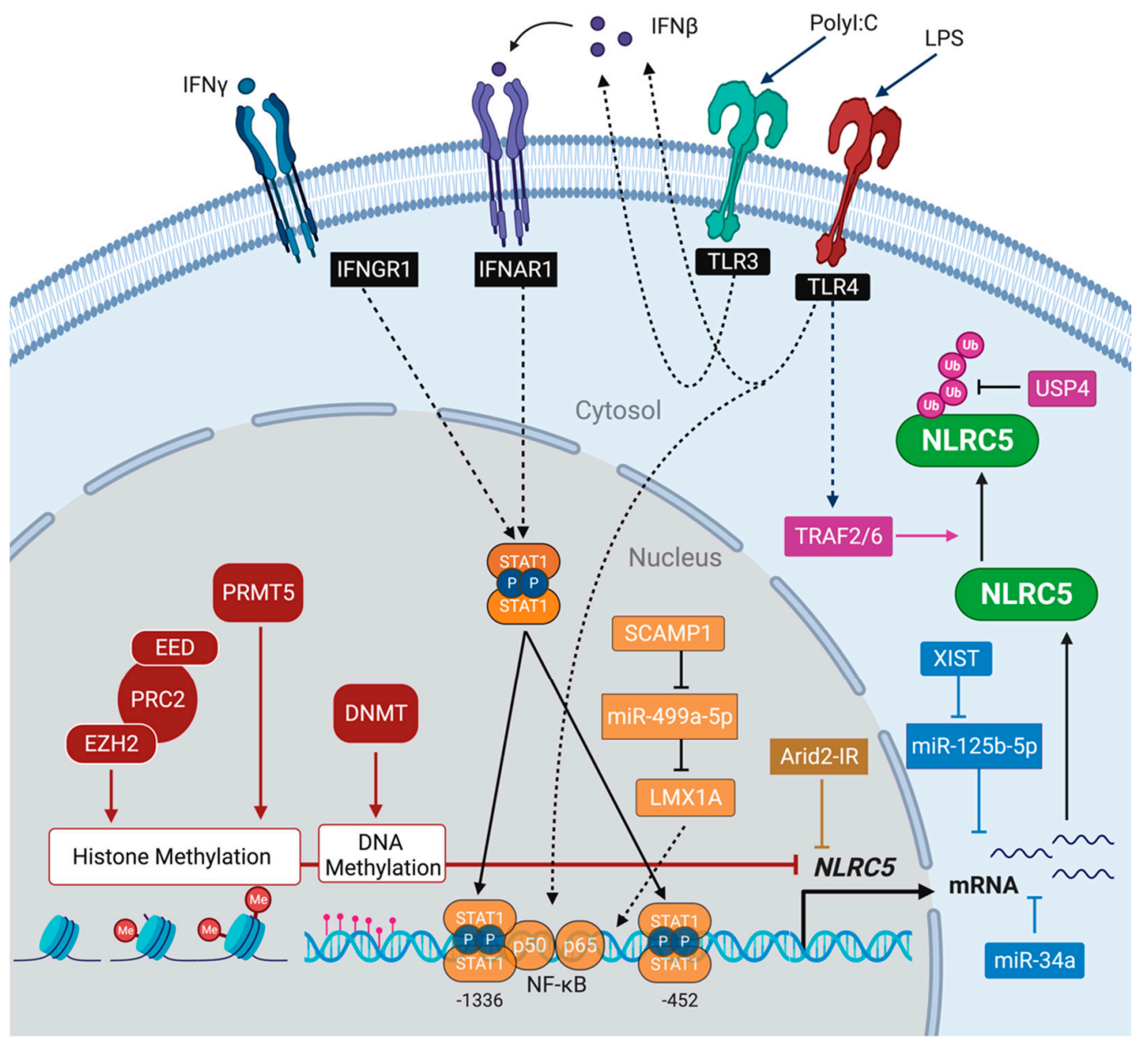

Figure 3. Regulation of NLRC5 gene expression. IFN $\gamma$ strongly induces NLRC5 gene expression through transcriptional activation of STAT1. STAT1 homodimers bind the GAS sequences in the NLRC5 promoter (-452, -1336). Type-I IFNs, induced by TLR ligands also induce NLRC5 via STAT1 activation. NF- $\kappa B$ activation by TLRs can synergize with STAT dimers by binding to the distal GAS site. NLRC5 is regulated by (i) epigenetic modifications of its promoter as well as at the (ii) transcriptional, (iii) post transcriptional and (iv) post-translational levels as detailed below: (i, factors indicated in burgundy color) Epigenetic regulation. NLRC5 promoter may be repressed by DNA methylation by DNA methyl transferases (DNMT), histone lysine methylation by the polycomb repressive complex 2 (PRC2) (containing lysine methyltransferase EZH2 [Enhancer of Zeste Homolog 2] and EED [Embryonic Ectoderm Development]) or histone lysine methylation by protein arginine methyltransferase 5 (PRMT5). (ii, orange) Transcriptional activators (STAT1 and NF- $\mathrm{BB}$ ) and their modulators. The LncRNA Arid2-IR (AT-rich interactive domain 2-intronic region) binds to the NLRC5 promoter and prevents its transcription. The lncRNA SCAMP1 (Secretory carrier-associated membrane protein 1) modulates NLRC5 transcription by removing miRNA miR499-5p, thereby relieving its repressive effect on LMX1A (LIM homeobox transcription factor 1) that binds to multiple sites at the NLRC5 promoter. (iii, brown, blue) Post-transcriptional regulation by miRNAs. miR-34a and miR-125b-5p downregulate NLRC5 expression by destabilizing mRNA and inhibiting translation. miR-125b-5p is regulated by the lncRNA XIST. (iv, purple) Post-translation regulation. NLRC5 is ubiquitinated by the TRAF2/ 6 complex induced by TLR signaling. Ubiquitin-specific protease 14 (USP14) deubiquitinates NLRC5. 
A recent CRISPR screen aimed at identifying genes responsible for low MHC-I expression in cancer cells identified the evolutionarily conserved polycomb repressive complex 2 (PRC2), which is known to modulate gene expression during embryonic development via histone methylation, and causes repressive histone methylation not only at MHC-I and APM gene promoters but also at the NLRC5 promoter [180]. This study implicated the lysine methyltransferase Enhancer of Zeste Homolog 2 (EZH2), a component of the $\mathrm{PRC} 2$, in mediating tri-methylation of histone H3 on lysine 27 (H3K27me3). This study also showed that pharmacological inhibition of EZH2 resulted in basal STAT1-independent restoration of MHC-I that was further upregulated by IFN $\gamma$ stimulation. This could result from the combined effects of promoter de-repression and NLRC5-mediated transactivation. Inhibition of Embryonic Ectoderm Development (EED), a WD40 repeats-containing protein that potentiates the action of EZH2 within the PRC2 complex, also upregulated MHC-I. NLRC5 gene transcription is also inhibited by protein arginine methyltransferase 5 (PRMT5) which catalyzes methylation of arginine residues on several histones (H2AR3, H3R2, H3R8 and H4R3) [181,182]. Modulation of the epigenetic signature at the NLRC5 promoter is also implicated in STAT1-independent upregulation of NLRC5 and MHC-I genes in pancreatic cancer cells exposed to ionizing radiation, although an earlier report attributed radiation-induced MHC-I upregulation in breast cancer cell lines to secretion of IFN $\beta[183,184]$. Increased CpG methylation of the NLRC5 and other IFN-I-responsive genes was reported in the genomic DNA of systemic lupus erythematosus patients that correlated with increased auto-antibody production, suggesting that epigenetic modulation of NLRC5 may also be influenced by systemic inflammation [185].Moreover, the chicken NLRC5 gene was reported to harbor two CpG islands, one near the proximal core promoter that is unmethylated, and the second one encompassing an additional STAT1 binding site (distal to the STAT1-NF-kB site) that could be methylated [186]. Whether the mammalian NLRC5 promoter displays such additional regulatory elements and differential methylation patterns needs to be explored.

Recently, it was found that quiescent hair follicle stem cells and muscle stem cells downregulate the expression of MHC-I and APM genes by repressing NLRC5 in order to protect the stem cell pool from immune surveillance and destruction [187]. A previous study has shown that histone methylation represses the expression of MHC-I and APM genes in human embryonic and pluripotent stem cells [188]. It has also been well documented that cancer initiating cells of different cancers (melanoma, glioblastoma and lung cancer) express low MHC-I that would protect them from CTL-mediated destruction, facilitating generation of immune escape variants and causing cancer recurrence after therapy [189-194]. Hence, it appears that the downregulation of NLRC5 and MHC-I in cancer cells could be a part of the global genetic de-differentiation program that accompanies progressive cancer growth in order to maintain the cancer initiating cell population rather than an immune escape program. This idea is supported by the involvement of histone methylases PRC2 and PRMT5, which play important roles in modulating gene expression during embryonic development, in repressing the NLRC5 gene promoter [180,181].

Transcription of NLRC5 is also subject to regulation by long non-coding RNA (lncRNA). A recent study showed that the lncRNA Arid2-IR inhibits NLRC5 gene expression and implicated this pathway in promoting renal inflammation [195]. The lncRNA Arid2-IR, located within the intronic region of AT-rich interactive domain 2 gene, was identified by RNAseq analysis of TGF $\beta$-mediated inflammatory pathways in kidney diseases and renal fibrosis [196]. Arid2-IR, induced by Smad3, enhances IL-1 $\beta$-induced NF- $\mathrm{kB}$ signaling without affecting TGF $\beta$ signaling. Zhou and colleagues discovered that Arid2-IR binds to the NLRC5 promoter and prevents its transcription to maintain NLRC5 expression in medullary renal tubular epithelial cells at the basal level (Figure 3). However, during inflammation, inflammatory cytokines such as IL- $1 \beta$ induce the expression of filamin A, which traps Arid2-IR in the cytosol, relieving its suppressive effect in the nucleus and leading to increased NLRC5 expression and attenuation of NK-KB signaling (discussed later in this section). Zong et al., implicated another lncRNA in modulating NLRC5 gene 
transcription [197]. Investigating the poor survival of glioma patients with high expression of the lncRNA SCAMP1 (Secretory carrier-associated membrane protein 1), this study showed that SCAMP-1 acts as a sponge for the miRNA miR499a-5p, thereby relieving its repressive effect on the LIM homeobox transcription factor 1, alpha (LMX1A) that binds the promoter region of the NLRC5 gene (Figure 3) at multiple sites $(-1168,-1452,-1734$ relative to TSS). Whether differential expression of these IncRNAs could contribute to differential levels of basal NLRC5 expression in various tissues remains to be tested.

Interestingly, the Kufer laboratory cloned different NLRC5 isoforms from human leukocyte cDNA library, arising from alternate splicing and differing in the C-terminal region, raising the possibility that the NLRC5 isoforms may be destined for different functions within the leukocyte subpopulations [137]. However, unlike the CIITA isoforms that arise from different start codons and are tightly controlled by independent promoters in a cell-specific manner [198,199], the NLRC5 isoforms vary in their C-terminal LRRs. While it is conceivable that they may carry out different effector functions, whether their expression is also differentially regulated is not known.

Expression of NLRC5 is also regulated at the post-transcriptional and post-translational levels (Figure 3). The HIV-1 TAT protein was shown to upregulate the micro-RNA miR-34a in microglial cells, leading to downmodulation of NLRC 5 and increased NF- $\mathrm{KB}$ activation that could contribute to neuronal inflammation [200]. On the other hand, miR-34a was reported to be downmodulated by human papilloma virus-16 (HPV-16) in cervical cancer cells, resulting in the upregulation of NLRC5 and consequent attenuation of NF- $\mathrm{KB}$ activation and pro-inflammatory cytokine production and virus persistence [201]. Zong et al., implicated miR-125b-5p in downmodulating NLRC5 expression [202]. This study showed that the lncRNA XIST (X-inactivation-specific transcript), upregulated in breast cancer cells, promotes cell proliferation, migration and invasion by increasing NLRC5 expression through sponging off miR-125b-5p. An obligate intracellular bacterium Orientia tsutsugamushi, which causes scrub typhus by infecting mononuclear and endothelial cells, was shown to attenuate NLRC5 expression in HeLa cells at the post-transcriptional level [203]. The blockade of NLRC5 protein expression by O. tsutsugamushi required bacterial protein synthesis and possibly host cell factors as inhibition of NLRC5 protein expression was reversible in a monocytic cell line THP-1 but not in endothelial cells. Molecular mechanisms underlying the inhibition of NLRC5 expression by O. tsutsugamushi at the post-transcriptional level remains to be elucidated.

NLRC5 attenuates the NF- $\mathrm{kB}$ pathway by interfering with the IKK complex, which is composed of IKK $\alpha$ and IKK $\beta$ kinases and the regulatory subunit NEMO (also called IKK $\gamma$ ). IKK-mediated phosphorylation leads to ubiquitination and proteasomal degradation of IкB, allowing NF- $\mathrm{KB}$ to translocate to the nucleus and induce gene transcription. Cui et al., have shown that, in LPS stimulated cells, NLRC5 inhibits IкB phosphorylation and degradation by binding to IKK $\alpha$ and IKK $\beta$, thus preventing the IKK complex formation [135]. In an effort to elucidate the mechanisms underlying this regulation, the Cui group showed that TLR4 stimulation activates the TRAF2/ 6 complex, which ubiquitinates NLRC5 on Lys1178 residue, presumably leading to its degradation and release of IKK $\alpha$ and IKK $\beta$ to complex with IKK $\gamma[204,205]$ (Figure 3) This study also showed that the ubiquitin-specific protease 14 (USP14) deubiquitinates NLRC5 to sustain the NLRC5-mediated inhibition of NF- $\mathrm{KB}$ activation. The NF- $\mathrm{kB}$ signaling pathway, which is activated in cancer cells by various stimuli including cytokines, growth factors, environmental stress and DNA damage, is implicated in cancer development, progression, metastasis and resistance to therapy $[206,207]$.

A recent genome wide CRISPR screen aimed at identifying genes that regulate MHC expression, has identified several molecules in addition to the known transcription factors and promoter components [208]. Among them SUGT1 (human homologue of yeast SGT1), which has been previously reported to modulate NLR protein functions [209,210], appears to promote MHC-I expression by stabilizing NLRC5. SGT1 interacts with SKP1 within the SCF (Skp1-Cullin-F box) family of Ub ligase complex [211,212]. Further work is needed to 
determine how SUGT1 stabilizes NLRC5 protein. Overall, even though NLRC5 is repressed mainly by epigenetic mechanisms of DNA as well as histone methylation and histone deacetylation at its promoter, additional mechanisms involving miRNAs targeting NLRC5 and posttranslational modifications of NLRC5 protein could also contribute to reduced NLRC5 protein expression in cancers. The resulting downregulation of MHC-I expression and increased NF- $\mathrm{kB}$ activation can act in synergy to promote cancer growth.

\section{Impact of NLRC5 on Antitumor Immunity}

As the loss of MHC-I expression is a common immune escape mechanism in cancers and NLRC5 is the key transcriptional activator of MHC-I genes, our laboratory studied the impact of NLRC5 on antitumor immunity using the B16.F10 murine melanoma model [29]. The poorly immunogenic B16 cells are widely used in cancer immunotherapy studies [213] These cells display negligible MHC-I expression that can be induced by IFN $\gamma$ stimulation, indicating soft/reversible lesions in the MHC-I expression pathway [86]. We showed that stable expression of NLRC5 in B16 cells induces MHC-I and APM genes, upregulates cell surface MHC-I expression and promotes the processing and presentation of an endogenous tumor antigenic peptide from PMEL-1 (gp100) protein [29]. The NLRC5 expressing B16 cells showed reduced growth in immunocompetent C57BL/ 6 mice but not in Rag1-deficient mice, which lack mature T cells and B cells, indicating that NLRC5 expression promoted lymphocyte-mediated antitumor immunity. This was further supported by the reversal of reduced tumor growth in C57BL/ 6 mice depleted of $\mathrm{CD}^{+} \mathrm{T}$ lymphocytes. Moreover, immunization with irradiated NLRC5 expressing cells conferred protection against challenge with parental B16 cells. These findings indicate that MHC-I expression in APC is not sufficient, whereas MHC-I expression in tumor cells is necessary, to elicit protective antitumor immunity against MHC-I negative tumors [29]. Following this report, several other studies have documented similar findings (Table 1). In studying PRMT5-mediated inhibition of Nlrc5 gene expression, Kim et al., confirmed that NLRC5 expression in B16 cells augmented MHC-I expression and reduced in vivo tumor growth [181]. Kalbasi et al. rendered B16 cells unresponsive to IFN by CRISPR-mediated deletion of Jak1, and showed that stable NLRC5 expression in these cells upregulated MHC-I and rendered them susceptible to immune elimination in C57BL/ 6 mice by adoptively transferred PMEL-1 TCR transgenic CD8 ${ }^{+} \mathrm{T}$ cells [214]. In pancreatic adenocarcinoma cells, the Nlrc5 gene was shown to be induced by irradiation, resulting in increased susceptibility to anti-PD-L1 immune checkpoint inhibitor therapy [183]. The authors speculate that irradiation may alter epigenetic modification of the Nlrc5 gene promoter. All these studies lend support to the notion that restoration of NLRC 5 expression in cancer enhances MHC-I expression in tumor cells leading to efficient antitumor immune response and CTL-mediated killing of tumor cells.

Table 1. Studies ascribing antitumor or protumor roles to NLRC5.

\begin{tabular}{|c|c|c|c|c|}
\hline Cancer Type & Model Systems & Study Description & Molecular Effects & Ref. \\
\hline \multicolumn{5}{|c|}{ NLRC5 as a tumor suppressor } \\
\hline Melanoma & $\begin{array}{l}\text { Murine B16.F10 cell line } \\
\text { stably expressing NLRC5 }\end{array}$ & $\begin{array}{l}\text { NLRC5 limits tumor growth and } \\
\text { metastasis in C57BL/ } 6 \text { mice by } \\
\text { activating antitumor CD8 }{ }^{+} \\
\text {T lymphocytes; }\end{array}$ & $\begin{array}{l}\text { NLRC5 upregulates MHC-I, } \\
\beta 2 \mathrm{M}, \text { PSMB9, PSMB8, TAP1 } \\
\text { gene expression; } \\
\text { NLRC5 promotes presentation } \\
\text { of peptide from gp100 (Pmel-1) } \\
\text { tumor antigen }\end{array}$ & [208] \\
\hline Melanoma & $\begin{array}{l}\text { PRMT5 knockdown in } \\
\text { B16.F10 and Yummer1.7 } \\
\text { cell lines; } \\
\text { B16.F10 stably } \\
\text { expressing NLRC5 }\end{array}$ & $\begin{array}{l}\text { Induction of endogenous NLRC5 } \\
\text { by PRMT5 knockdown, or stable } \\
\text { NLRC5 expression inhibited } \\
\text { tumor growth in C57BL/ } 6 \text { mice }\end{array}$ & $\begin{array}{l}\text { PRMT5 reduces NLRC5 } \\
\text { expression by promoting } \\
\text { methylation of Arg residues } \\
\text { on histones }\end{array}$ & [176] \\
\hline
\end{tabular}


Table 1. Cont.

\begin{tabular}{|c|c|c|c|c|}
\hline Cancer Type & Model Systems & Study Description & Molecular Effects & Ref. \\
\hline Melanoma & $\begin{array}{l}\text { Jak1 }{ }^{-/-} \text {B16 cell line } \\
\text { expressing NLRC5 }\end{array}$ & $\begin{array}{l}\text { NLRC5 rendered Jak1 }{ }^{-/-} \text {B16 } \\
\text { cells susceptible to killing by } \\
\text { adoptively transferred Pmel-1 } \\
\text { TCR transgenic CD8 }{ }^{+} \text {T cells } \\
\text { in vivo }\end{array}$ & NLRC5 upregulates MHC-I & [210] \\
\hline $\begin{array}{l}\text { Pancreatic } \\
\text { adeno-carcinoma } \\
\text { (PDAC) }\end{array}$ & $\begin{array}{l}\text { Murine Panc02 cell line } \\
\text { expressing a model } \\
\text { antigenic peptide } \\
\text { SIYRYYGL fused to GFP } \\
\text { (Panc02SIY100) }\end{array}$ & $\begin{array}{l}\text { Gamma irradiation induces } \\
\text { NLRC5 expression renders } \\
\text { Panc02 cells susceptible to } \\
\text { anti-PD-L1 in vivo; } \\
\text { Stable NLRC } 5 \text { expression in } \\
\text { Panc02SIY100 promotes } \\
\text { activation of 2C TCR transgenic } \\
\text { CD8 }{ }^{+} \text {T lymphocytes }\end{array}$ & $\begin{array}{l}\text { Gamma irradiation induces } \\
\text { MHC-I independently of } \\
\text { IFN-I signaling }\end{array}$ & [178] \\
\hline
\end{tabular}

\section{NLRC5 as a tumor promoter}

\begin{tabular}{ll}
\hline Hepatocellular & Human HCC specimens; \\
carcinoma (HCC) & HCC cell lines: HepG2, \\
& SMMC-7721, BEL-7402; \\
& stable expression or \\
& knockdown of NLRC5
\end{tabular}

HCC specimens and cell lines display elevated NLRC5 expression; NLRC5 promotes cell proliferation, migration and invasion; NLRC5 knockdown has opposite effect \& reduces HepG2 tumor growth in nude mice

Hepatocellular $\quad$ HepG2 cell line
carcinoma
carcinoma

\section{NLRC5 overexpression in} HepG2 cells promotes cell growth via upregulating VEGF-A

$\begin{array}{ll}\text { Clear cell renal cell } & \text { Human ccRCC specimens } \\ \text { carcinoma (ccRCC) } & \text { Human ccRCC cell lines } \\ & \text { Caki-1, 786-O and 769-P }\end{array}$
ccRCC specimens and cell lines display elevated NLRC5 expression; NLRC5 promotes cell proliferation, migration and invasion; NLRC5 knockdown causes opposite effects and reduces $786-\mathrm{O}$ tumor growth in nude mice

\begin{tabular}{ll}
\hline Giloma & $\begin{array}{l}\text { Human glioma tissues, } \\
\text { cell lines U87, U251 }\end{array}$
\end{tabular}

High grade glioma tissues and cell lines display elevated NLRC5 expression due to high levels of lncRNA SCAMP1; NLRC5 knockdown restrains cell proliferation, migration \& invasion and increases apoptosis

Esophageal squamous ESCC cell lines cell carcinoma (ESCC) NLRC 5 overexpression in ESCC cell lines promotes cell proliferation, colony formation and cell cycle progression

Breast cancer

Breast cancer tissues, cell lines MCF-7, MDA-MB-231

\author{
MCF-7 and MDA-MB-231 show \\ increased proliferation, \\ migration and invasion due to \\ elevated expression of XIST \\ lncRNA, which \\ upregulates NLRC5
}

NLRC5 expression promotes Wnt $/ \beta$-catenin signaling and c-Myc, CyclinD1, MMP3 expression; $\beta$-catenin inhibitor iCRT3 attenuated the effects of NLRC 5 overexpression

NLRC5 promotes VEGF-A expression via AKT activation

NLRC5 promotes $\beta$-catenin, c-Myc, CyclinD1, MMP2, MMP9 expression

SCAM1-1 sponges off
miR-499a-5p, which targets
LMX1A; LM1A binds NLRC5
promoter and is proposed
to augment NLRC5
expression to activate the
Wnt/ $\beta$-catenin pathway
miR-4319 targets NLRC5; low
miR-4319 in ESCC upregulates
NLRC5 expression

XIST sponges off miR-125b-5p, which 


\section{Tumor Promoting Potential of NLRC5}

Contrary to the studies highlighting the role of NLRC5 in reducing tumor growth by eliciting antitumor immunity, several reports suggest a potential role of NLRC5 in promoting cancer growth (Table 1). Li and colleagues observed elevated expression of NLRC5 protein in human hepatocellular carcinoma (HCC) specimens and in human HCC cell lines HepG2, SMMC-7721 and BEL-7402, and investigated the effects of NLRC5 knockdown and overexpression on cell growth [215]. NLRC5 overexpression promoted cell growth, motility and migration, and these effects were accompanied by elevated expression of $\beta$-catenin and downstream oncogenic signaling molecules. These NLRC5mediated effects were reversed by the $\beta$-catenin inhibitor iCRT3. Knockdown of NLRC5 had similar effects and reduced the growth of HepG2 cells as a xenograft in BALB/c nude mice lacking adaptive immune cells. The same group reported similar NLRC5mediated effects on clear cell renal cell carcinoma (ccRCC) cells [216]. Another recent study also implicated NLRC 5 in promoting the growth of glioma cells by activating the Wnt/ $\beta$-catenin pathway [197]. NLRC5 was also shown to activate the PI3K/AKT signaling pathway in human HCC and endometrial cancer cell lines and promote cell growth $[217,218]$. In esophageal squamous cell carcinoma (ESCC) and breast cancer cell lines, elevated NLRC5 expression was associated with lower levels of miR-4319 and miR125b-5p, which reportedly target NLRC5 [202,219]. In ESCC cell lines, overexpression of NLRC5 promoted cell proliferation, colony formation and cell cycle progression. All the above reports implicating NLRC5 in promoting tumor growth in HCC, ccRCC, glioma and ESCC are based on in vitro studies on cell lines as well as in mice lacking a functional adaptive immune system, whereas NLRC5 inhibited growth of melanoma and PDAC cells in mice with a competent immune system. These discordant results may result from the antitumor immune response elicited by NLRC 5 overcoming any growth stimulatory functions of NLRC5 in cancer cells. It is also possible that the different outcomes of NLRC5 may also depend on the tumor type. In this context, it is noteworthy that the Kobayashi group has observed elevated NLRC 5 mRNA expression in liver, colon and brain cancer tissues within the TCGA study cohorts [28]. Even though this elevated NLRC5 expression was thought to result from high inflammatory conditions in these cancers, studies showing NLRC5 protein expression by immunohistochemistry reveal increased staining within epithelial cells $[215,217]$. The possibility that the antitumor versus pro-tumorigenic roles of NLRC5 may be influenced by the mutational load and the frequency of neoantigen generation of different cancers [56] also need to be considered. In this context, in colon cancers with microsatellite instability phenotype, NLRC5 mutations were reported to underlie a significant proportion of reduced MHC-I expression and contribute to immune evasion [220].

\section{Restoring MHC-I Expression in Cancers}

Despite extensive documentation of defects in MHC-I expression and antigen presentation in cancer cells, limited progress has been made in the efforts to reverse these defects $[24,25,109,110]$. As APM and $\beta 2 \mathrm{M}$ are necessary to generate stable MHC-I:peptide complex, introducing TAP1 and $\beta 2 \mathrm{M}$ genes using recombinant viral vectors was shown to restore surface MHC-I expression and elicit antitumor response in experimental tumor models [221-224]. While this approach may be useful if the MHC-I expression defect is caused by APM or $\beta 2 \mathrm{M}$ deficiency, it will not be useful if MHC-I genes were defective or their expression blocked.

IFN $\gamma$ is a potent inducer of MHC-I and APM genes and promotes antigen processing by changing the proteasome constituents. IFN $\gamma$ has been shown to restore MHC-I expression in cancer cells, suggesting its potential use to correct MHC-I defects [86]. However, cancers develop various defects to impair IFN signaling pathways [84,104,105], indicating that IFN $\gamma$ therapy may not be useful in all cases. Moreover, IFN $\gamma$ is a potent inducer of PD-L1, a ligand to the immune checkpoint receptor PD-1 [225-228]. Indeed, induction of PD-L1 by IFN $\gamma$ produced by antitumor CTLs has been referred to as 'adaptive immune 
suppression' [229]. Furthermore, IFN $\gamma$ can modulate many cellular components of the tumor microenvironment to induce promo-tumorigenic effects, limiting its potential use in cancer immunotherapy $[230,231]$. Curiously, IFN $\gamma$ represses the expression of antiinflammatory genes in macrophages via promoting recruitment of EZH2 and increasing H2K27me3 methylation, the same events that are implicated in repressing NLRC5 in stem cells $[180,232]$. Since IFN $\gamma$ strongly induces NLRC5 gene expression, further studies in normal and cancer cells are needed to resolve the conundrum of STAT1-mediated gene activation and $\mathrm{EZH} 2$-mediated epigenetic repression of the same target genes.

IFN $\gamma$ shares key elements of the JAK-STAT signaling pathway with type-I interferons that includes IFN $\alpha$, IFN $\beta$ and several other members [228,233]. Whereas IFN $\gamma$ receptors activate JAK1 and JAK2 and form STAT1 homodimers (also called gamma activated factor, GAF), IFN-I receptors activate JAK1 and TYK2, and form both STAT1 homodimers and STAT1:STAT2 heterodimers. Whereas STAT1 homodimers bind GAS sequences (present in IRFs and NLRC5 gene promoters), STAT1 homodimers and STAT1:STAT2 heterodimers interact with IRF9 to form the ISGF3 (interferon-stimulated gene factor 3) that binds the ISRE (IFN-stimulated response element, present in MHC-I and APM genes) to stimulate the expression of IFN-stimulated genes (ISG) and IRFs [228,233,234]. IFN-I, which confer resistance to viral infections by inhibiting transcription, degrading RNA and inhibiting protein translation, also results in cell growth inhibition and apoptosis via diverse mechanisms that can limit cancer progression $[235,236]$. IFN-I also promotes antitumor immunity by increasing MHC-I expression and APC functions [237,238]. Radiation and chemotherapeutic agents induce cancer cell autocrine and paracrine effects of IFN-I, which is crucial to mediate their antitumor activity $[184,236,239,240]$. However, the potential use of IFN-I as a cancer therapeutic has been limited by its systemic toxicity, although efforts are being made to overcome this limitation [238]. Besides, many cancers develop unresponsiveness to IFN-I in order to overcome its cytostatic effects by downmodulating its receptor chains, upregulating the negative regulators of the JAK-STAT pathway such as SOCS1, or reducing the expression of STAT1 [241,242]. Nonetheless, IFN-I unresponsiveness renders cancer cells susceptible to oncolytic viruses (OV), which are being exploited to kill cancer cells while sparing normal cells [243]. OV can also be armed with genes encoding immunostimulatory molecules such as tumor antigens, $\mathrm{T}$ cell costimulatory molecules and cytokines including IFN $\beta$ [244,245].

As discussed earlier, epigenetic repression of MHC-I expression and its possible reversal by epigenetic modifiers has been recognized for over two decades. Epigenetic modulation of gene expression is a fundamental process of chromatin remodeling that regulates embryonic development, cellular differentiation and adaptation to environmental challenges [246,247]. These mechanisms can contribute to the initiation and progression of cancer. Epigenetic modulation of gene expression can occur by DNA methylation of CpG island near promoters, histone methylation especially trimethylation of lysine on histone H3 (H3K27me3) and histone deacetylation. Inhibitors of DNA methyltransferases (DNMTi: 5-Aza, decitabine), histone deacetylases (HDACi: Vorinostat, Panobinostat, valproic acid, etc.) and histone methyltransferases (HMTi: EZH2 inhibitors -Tazemetostat) are undergoing clinical trials for cancer treatment with some being already approved [248]. 5-Aza and Trichostatin-A have been shown to derepress MHC-I and APM (TAP1) genes and restore MHC-I expression in human and mouse cancer cell lines as well as in xenograft models in mice [104,111-113,115-118,249]. The recent findings that NLRC5 gene expression itself is repressed by methylation of DNA and histones in cancer cells and primary cancers, and that inhibition of these repressive epigenetic mechanisms restores MHC-I expression raise the possibility of using epigenetic therapy to correct defective MHC-I expression in cancers $[28,180,181]$. However, certain limitations of epigenetic drugs may restrain their potential use to restore MHC-I via derepressing NLRC5. Epigenetic drugs have shown limited efficacy on solid tumors despite their remarkable success against hematopoietic cancers [250]. Another key challenge facing epigenome therapeutics is off- target effects [251,252]. Hence, in addition to using epigenetic modifiers, other ap- 
proaches should be envisioned to restore MHC-I expression in cancers showing defective NLRC5 expression.

By comparing gene expression in MHC-I positive and negative variant of a mouse fibrosarcoma clone B9, Garcia-Lora and colleagues discovered that the loss of fragile histidine triad (Fhit) tumour suppressor gene expression was associated with the loss of MHC-I, $\beta 2 \mathrm{M}$ and APM gene expression [253]. Re-expression of Fhit restored the MHC-I expression in this clone. The same group recently reported that in MHC-I negative breast cancers the loss of NLRC 5 is less frequent than the loss of FHIT, and that FHIT could be used to restore MHC-I expression [254]. As FHIT does not upregulate NLRC5 expression, the molecular pathways by which FHIT upregulates MHC-I remains to be determined [254].

\section{NLRC5-Independent MHC-I Expression}

A recent study shows that MHC-I expression in tumor cells can be induced independently of NLRC5 [214]. Clonal populations of B16 cells, rendered unresponsive to IFNs by the deletion of Jak1 and also deleted of the Nlrc5 gene, showed increased MHC-I expression following treatment with a nanoplexed version of polyI:C (BO-112). BO-112, which activated TLR3, resulted in NF- $\mathrm{KB}$ activation, and inhibition of NF- $\mathrm{KB}$ signaling abolished MHC-I expression. This study implies that increased NF- $k B$ activity at the enhancer A site of MHC-I gene promoter may be sufficient to restore MHC-I expression without transactivating the NLRC5-dependent enhanceosome. Given the well documented role of NLRC5 in attenuating NF- $\mathrm{kB}$ signaling, the above study raises the possibility that MHC-I expression can be restored even in NLRC 5 deficient cancers by inducing NF- $\mathrm{KB}$ signaling. However, these findings need to be replicated in other model systems. Moreover, it remains to be seen whether such an approach will lead to strong enough induction of antitumor immunity that can overcome the potentially harmful deregulation of NF- $\mathrm{kB}$ signaling. It is also noteworthy that IFN $\gamma$ stimulation upregulated MHC-I in NLRC5-deficient T cells, B cells and macrophages, albeit to a lower extent than wild type controls [140]. Although CIITA may compensate for the loss of NLRC5 in B cells and macrophages after IFN $\gamma$ stimulation, which can be tested in mice lacking both NLRC 5 and CIITA, other unknown mechanisms likely underlie similar MHC-I induction in NLRC5 deficient T cells.

\section{Role of NLRC5 in Cancer Immune Surveillance}

The ability of NLRC5 to promote cancer immunogenicity by upregulating MHC-I and APM may also contribute to cancer immune surveillance. Whether tumor cell intrinsic NLRC5 expression is essential, or NLRC5 expression in APCs is sufficient, preventing the emergence of neoplastic clones remains to be addressed. Our findings on the B16 melanoma model indicate that NLRC5 expression in APCs alone is not sufficient to induce antitumor immunity, and that NLRC5 expression in tumor cells is crucial to elicit antitumor immune response, which was also effective against parental B16 cells that display reduced MHC-I expression [29]. It is likely that APCs acquire MHC-I bearing tumor antigenic peptides from NLRC5 expressing B16 cells, presumably via the process of 'trogocytosis' [255,256], and that such 'cross-dressed' APCs induce antitumor immune response more efficiently than APCs processing the antigens of parental B16 cells. This process may also occur for newly emerging neoplastic clones, contributing to cancer immune surveillance. It can be envisaged that newly arising immune escape variants may be able to generate effective immune response as long as they express NLRC 5 and MHC-I. As ablation of the Nlrc5 gene does not completely abolish MHC-I expression, especially in non-hematopoietic cells, it should be possible to test using NLRC5-deficient mice whether NLRC5 plays a crucial role in cancer immune surveillance and selection of immune escape variants.

NLRC5 not only transactivates classical MHC-Ia genes but also induces non-classical MHC-Ib genes, which may impact tumor immune surveillance. The non-classical MHCI molecules are encoded by genes within $\mathrm{H} 2-\mathrm{Q}, \mathrm{H} 2-\mathrm{T}$ and $\mathrm{H} 2-\mathrm{M}$ loci (each containing several genes) in mouse and non-orthologous HLA-E, -F, -G, MICA and MICB genes in human $[94,257,258]$. Most of the mouse MHC-Ib molecules and human HLA-E are broadly 
expressed whereas certain mouse MHC-Ib and human HLA-F and G show restricted expression pattern [94]. Most mouse MHC-Ib molecules and HLA-E present protein antigenic peptides $[94,95]$. These MHC-Ib molecules can activate unconventional CD8 ${ }^{+} \mathrm{T}$ cells bearing $\alpha \beta T C R$ to elicit rapid innate like effector functions that contribute to immune response against pathogens and neoplasms [95]. However, certain non-classical MHC-Ib molecules such as H2-T11/23 (also known as Qa-1) and HLA-E (the functional homologue of Qa-1) present a peptide derived from the leader sequences of classical MHC-Ia known as Qa-1 determinant modifier (Qdm), which delivers an 'inhibitory signal' to NK cells and $\mathrm{CD}^{+} \mathrm{T}$ cells upon engaging NKG2A receptor of the CD94/NKG2A family [259-261]. NK cell stimulation is determined by the net balance between inhibitory and activation receptor signaling. NK cells are activated by the failure to receive an inhibitory signal delivered by MHC-Ib molecules (missing self-recognition) as well as by signaling from activating receptors [262]. Thus, the interaction of NK cell inhibitory receptors with MHC-Ib serves to indirectly monitor defective MHC-Ia expression in cancer cells. However, cancer cells can evade NK cell-mediated killing by upregulating the expression of HLA-E that engage the NK cell inhibitory receptors and blocking this inhibitory signaling can boost antitumor NK and CTL responses [263-265]. Cancer cells also exploit HLA-G, which is expressed by fetal trophoblasts and maintain immune tolerance, for immune evasion $[266,267]$.

The promoters of $H L A-E, F, G$ genes harbor the SXY module and are induced by overexpressed NLRC5 in HEK293T cells $[130,268]$. In mice, NLRC5 deficiency was shown to decrease the expression of H2-M3, H-2T11/23 (Qa1) and H2-T18 (also known as Tla) [140,146,148]. By chromatin immunoprecipitation (ChIP) sequencing of NLRC 5 bound genomic sequences in $\mathrm{T}$ cells (which show maximal decrease in MHC-Ia expression in NLRC5 deficient mice) Ludigs et al., showed that NLRC 5 binds to the promoter regions of several MHC-Ib genes, including H2-Q4, H2-Q6, H2-Q7, H2-T10 and H2-T22 [158]. H2-M3 was also found to harbor potential NLRC 5 binding sites. These data corroborate the increased susceptibility of NLRC5 deficient T cells to increased NK cell mediated killing during viral infections [173]. Whether NLRC5 deficiency affects MHC-Ib expression in other tissues and cells, and how this would impact NK cell-mediated tumor killing and the development of adaptive antitumor immunity, are questions that need to be addressed. Analysis of the TCGA dataset revealed that the expression of $H L A-E,-F$ and $-G$ show very strong positive correlation with NLRC5 and CD8A similar to their association with classical MHC-Ia genes. It can be envisaged that NLRC5-deficient clones arising during cancer progression, lacking both MHC-Ia and MHC-Ib, would impair conventional and unconventional CD8 ${ }^{+} \mathrm{T}$ cell activation towards these clones but would favor NK cell activation. Distinguishing the impact of NLRC5-driven MHC-Ib expression from that of MHC-Ia expression and their contribution to cancer immune surveillance in human tissues will be very challenging. Studies on NLRC5 deficient mice and single cell RNAseq data from human cancers my shed light on this issue.

\section{Exploiting NLRC5 for Cancer Immunotherapy \\ 16.1. Restoring Cancer Immunogenicity}

The most obvious and direct application of NLRC5 to cancer immunotherapy would be to restore MHC-I expression in poorly immunogenic cancers (Figure 4). This approach will be beneficial in cancers displaying soft epigenetic alterations of MHC-I or MHC-I pathway genes that harbor the SXY module in their promoters. This can also be applicable to cancers that develop unresponsiveness to IFNs but will not be useful for cancers bearing 'hard' lesions of the MHC-I pathway genes such as deletion and nonsense mutations. Using NLRC5 to restore MHC-I will also circumvent the undesired side effect of using type-I and type-II IFN as they also induce the immune checkpoint blocker PD-L1 [226,229,269]. 


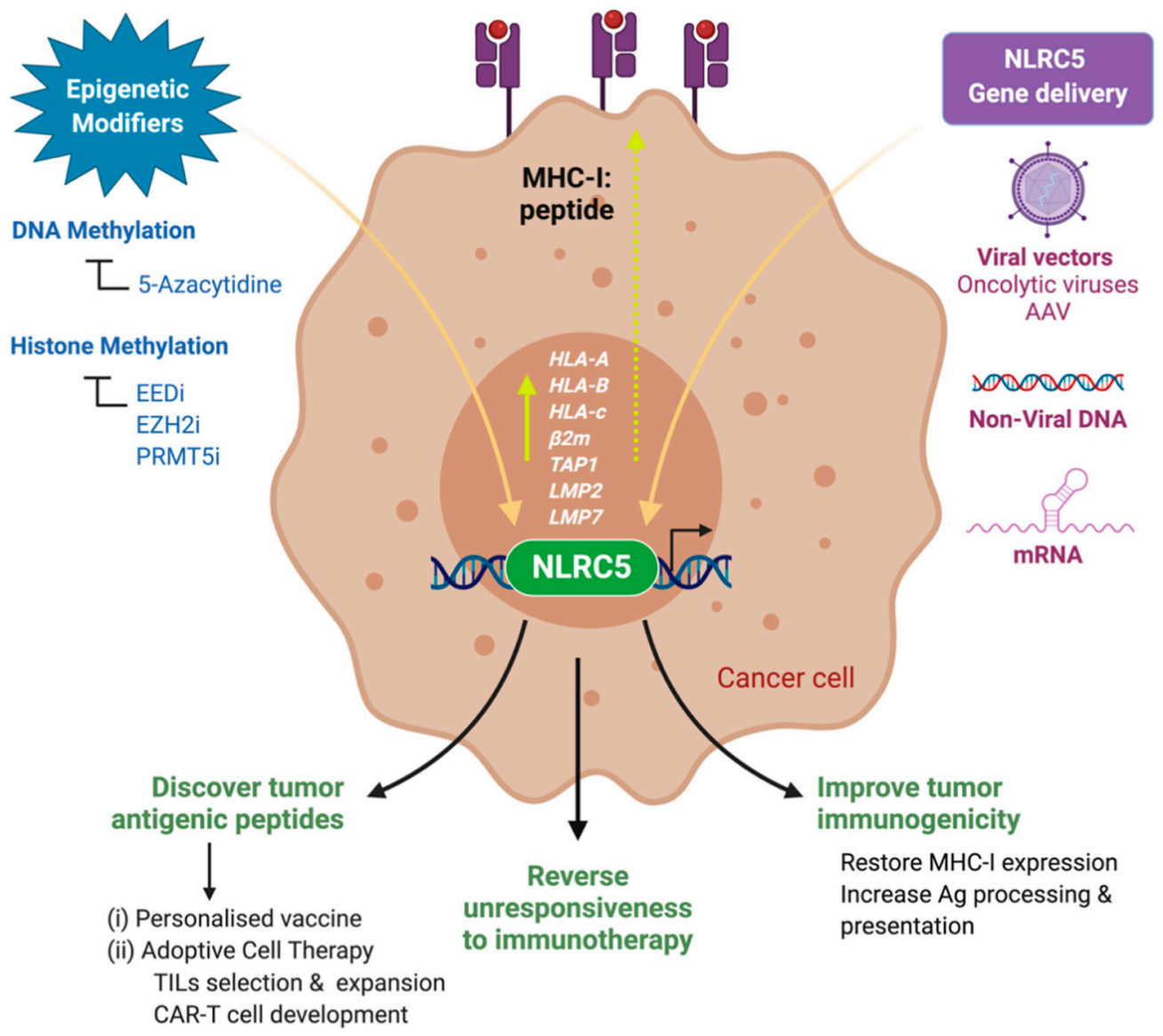

Figure 4. Strategies to restore NLRC5 expression in cancer cells and its potential applications for cancer immunotherapy. MHC-I low cancers can be treated with pharmacological agents to relieve epigenetic repression of NLRC5 that will also derepress MHC-I and APM genes. NLRC5 gene delivery using oncolytic viruses, naked DNA or mRNA will be useful on cancers with a dysfunctional NLRC5 gene. Restoration of NLRC5 can be exploited to improve tumor immunogenicity and CTL-mediated killing, and to reverse unresponsiveness to conventional cancer immunotherapy such as immune checkpoint inhibitors. NLRC5 can also be exploited for cancer neoantigen discovery that will find application in personalized cancer vaccines and adoptive cell therapy.

As discussed previously, using the inhibitors of enzymes involved in mediating epigenetic repression of NLRC5 via DNA methylation, histone methylation and histone deacetylation could be a feasible approach (Figure 4), but the off-target effects of these drugs may limit their use. This limitation can be mitigated by selective expression of NLRC5 in cancer tissues. However, unlike small molecule drugs that can be administered orally or parenterally, NLRC5 must be directly delivered to cancer cells and efficient delivery methods need to be developed. Delivery of NLRC 5 via oncolytic viruses could be one approach that can be tested as the many OV platforms are in advanced clinical trials for cancer immunotherapy [243,244]. However, oncolytic viruses exploit the loss of IFN-I signaling in cancer cells to specifically target them while sparing normal cells, and therefore their use will be limited in cancers that retain intact IFN-I signaling pathway and antiviral mechanisms. Even though arming OV with NLRC5 is a feasible approach that can achieve both tumor cell killing and elicit effective antitumor immunity, a potential caveat of this approach would be cancer cell lysis may precede effective NLRC5-mediated increase in MHC-I expression and tumor antigen presentation. An alternate and viable approach would be mRNA delivery systems [270]. Indeed, delivery of cytokines and co-stimulators have been shown to increase antitumor immune responses [271-273]. It may not be possible to deliver NLRC5 to every cell in the tumor mass. However, immune 
response elicited by NLRC5-expressing tumor cells can be effective against parental cells bearing low MHC-I [29]. Delivery of NLRC5 to cancers may also be combined with a limited use of epigenetic modifiers to relieve repression on MHC-I and APM promoters.

An important impediment to deliver NLRC 5 to cancer cells would be its large size. NLRC5 is a large $205 \mathrm{kDa}$ protein encoded by 49 exons [135], which puts constraints on accommodating the cDNA or RNA into any delivery vehicle. In this context, the Kufer lab has shown that a chimeric NLRC5 containing the NACHT and 4 LRRs of CIITA instead of its own 20 LRRs (Figure 2C,D) retained the ability to transactivate MHC-I genes [274]. Development of minimal NLRC5 constructs retaining the key functionality of transactivating MHC-I and APM genes, and the ability to induce antitumor immunity is a crucial step towards exploiting NLRC5 for intra-tumoral gene delivery.

\subsection{Identification of Immunogenic Peptides}

Another potential application of NLRC5 in cancer immunotherapy is its possible use for the discovery of immunogenic tumor antigenic peptides. Current approaches of tumor antigenic peptide discovery are geared towards using the genomic data to detect cancer-associated mutations within coding sequences and to predict whether the peptide sequence bearing the altered amino acid would bind MHC-I [55-57,275]. Even though this approach has led to the identification of immunogenic tumor antigenic peptides, it may not be robust enough to detect all possible tumor antigenic peptides that may be important for tumor immunosurveillance. This consideration is particularly important given the fact that a significant proportion of the MHC-I bound peptides arise from nonlinear peptide sequences arising from alternate splicing of mRNA, use of alternate start codons and proteasome-mediated peptide splicing and peptides arising from non-coding sequences [58-65]. Even though the relative importance of these alternate peptides in antitumor immunity is unclear, their possible role in cancer immune surveillance cannot be ignored. Therefore, direct identification of MHC-I-associated peptides (MAPs) from cancer cells compared to normal tissues would be informative. Unfortunately, identification of these peptides is hampered by the lack of reference databases to predict the genomic origin of these peptides. To overcome this limitation, the Perreault laboratory constructed a database of all possible protein sequences in an Epstein-Barr virus-transformed B cell line from RNAseq data that was translated in silico in all three reading frames in forward and reverse directions [60]. This study showed that noncoding genomic sequences and out-of-frame translation of exonic sequences contribute to nearly $10 \%$ of MAPs. A similar proteogenomic approach was used to discover novel TSA in high-grade serous ovarian cancer [62]. Even though it would be an enormous undertaking to generate such databases for cancers from every tissue type, an international consortium similar to TCGA can help create such a database in the foreseeable future. Cancer neoantigens discovered through these approaches can be used to induce a TSA-specific immune response, expand TSAspecific CTLs for ACT or generate TSA-specific CAR-T cells. In this endeavor, NLRC5 could be used to facilitate direct identification of MHC-I bound peptides from cancers that display low level of MHC-I expression. Cancer cell lines representative of different cancer types and primary cancer specimens transfected or treated with NLRC5 coding nucleic acids will not only upregulate MHC-I expression but also APM genes that will facilitate processing and presentation of tumor antigenic peptides to boost the power of proteogenomic cancer neoantigen discovery.

\subsection{Biomarker to Predict Responsiveness to Immune Checkpoint Therapy}

Another possible application of the current knowledge on NLRC5 would be to use NLRC5 expression as a biomarker to predict responsiveness to immune checkpoint inhibitor (ICI) therapy. Even though ICI therapy have revolutionized cancer immunotherapy with a low relapse rate and longer disease-free survival, it is effective only in a subset $(\sim 20 \%)$ of cancer patients [276-278]. Diverse factors, including an intestinal microbiome, may contribute to poor responsiveness to ICI [279-281]. Biomarkers that can reliably predict 
responsiveness to ICI therapy are not yet available [282]. As it is unlikely that a single biomarker would have the predictive power, efforts are being made to develop a scoring system using multiple parameters [283-285]. In parallel, combinatorial approaches using a second checkpoint inhibitor, radiation, chemotherapy, ACT using CAR-T cells and oncolytic virus therapy are being investigated to improve the outcome of ICI therapy [286-289]. However, the success of all these approaches relies on the expression of MHC-I:tumor Ag peptide on tumor cells. Obviously, tumors that repress MHC-I or APM will not efficiently induce antitumor T cells and will also evade CTLs, diminishing the effectiveness of ICI therapy. Expression of MHC-I itself could be one of the biomarkers to predict unresponsive cases. However, as discussed before, MHC-I defect could arise from hard/irreversible or soft/reversible genetic lesions, and the latter may include impaired NLRC5 expression. As NLRC5 is the most frequently affected MHC-I pathway gene in many human cancers, and NLRC5 expression positively correlates with patient survival in several cancers including melanoma, cervical cancer and bladder cancer, Yoshihama et al., proposed NLRC5 as a potential prognostic biomarker for tumor immune evasion [28]. In fact, identification of NLRC5 deficient cancers would also make it possible to identify patients who are likely to benefit from therapeutic restoration of NLRC5 (discussed in an earlier section) that can boost the effectiveness of ICI therapy and generate lasting antitumor immunity.

To use NLRC5 as a biomarker, appropriate reagents and methods need to be developed and validated. PCR based evaluation of NLRC5 gene expression in tumor biopsies would not be appropriate as NLRC5 is highly expressed in hematopoietic cells that infiltrate tumors. Immunohistochemical (IHC) detection of NLRC5, along with other markers routinely used in clinical oncology such as Ki67 and HER2 would be ideal. However, antibodies used for clinical diagnosis generally go through extensive validation in multiple institutions before being approved for diagnostic purpose [290,291]. Validation of the currently available monoclonal antibody generated by the Kufer laboratory [137] (clone 3H8, commercially available from MilliporeSigma), and generation and validation of other antibodies would be a step forward in this direction. A few studies have reported elevated NLRC5 protein expression in certain cancers that is associated with poor survival [216,292,293]. The IHC staining of NLRC5 in these studies was less than clear and the proposed mechanistic underpinnings of such negative correlations were tenuous. Developing optimized reagents and methods will clarify such nuances on the predictive potential of NLRC5 expression in cancers.

\section{Conclusions}

Since its discovery as the transcriptional coactivator of MHC-I and certain APM genes in 2010, NLRC5 has raised the hope of exploiting it to correct MHC-I expression defects in cancer immunity. This idea gained traction with the findings that the loss of NLRC5 expression resulting from genetic and epigenetic causes is the most common mechanisms of MHC-I deficiency in cancers, and that loss of NLRC5 has poor prognosis for many cancers. NLRC5 can be used not only to restore MHC-I expression and tumor immunogenicity but also to discover cancer antigenic peptides and to predict unresponsiveness to cancer immunotherapy. However, certain limitations of using NLRC5 must be overcome to realize the translational potential of NLRC5. Nonetheless, recent advances in understanding the epigenetic regulation of NLRC5 has opened alternate approaches to restore MHC-I expression in cancers. There are also several outstanding questions on the regulation of NLRC5 expression and functions that are elaborated throughout the review. The key questions are summarized below.

\section{Outstanding Questions}

1. What is the basis of differential NLRC5 expression in various non-hematopoietic tissues? Different studies on NLRC5 deficient mice have reported varying levels of NLRC5 mRNA. Given that NLRC 5 expression is modulated by IFNs and TLRs, and NLRC5 is also regulated at post-transcriptional level by miRNAs and lncRNAs, evaluation of NLRC5 
mRNA and protein levels in normal mouse and human tissues will be informative. Whether the NLRC5 isoforms described in human leukocytes are also expressed in somatic cells also needs to be addressed.

2. Is the epigenetic control of NLRC5 expression differentially regulated in different cell types? EZH2-mediated histone methylation represses NLRC5 in stem cells and cancer cells, whereas IFN $\gamma$ promotes the same events in macrophages on certain genes. As IFN $\gamma$ strongly induces NLRC5 gene expression, it will be informative to dissect the impact of STAT1-mediated transcriptional activation on different modes of epigenetic repression of NLRC5.

3. Why does the predictive potential of NLRC 5 expression vary in different cancers? In TCGA study cohorts, not all cancers show reduced NLRC5 expression and low NLRC5 expression is not associated with poor prognosis in all cancers. In fact, liver, colon and brain cancer tissues show elevated NLRC 5 expression, which is thought to result from high inflammatory conditions. Some studies even reported that high NLRC5 is associated with poor prognosis, especially in HCC. As the TCGA datasets represent only bulk mRNA from cancer, stromal and immune cells, additional parameters such as immune and stromal cell signatures could be used to stratify the TCGA study cohorts and evaluate the predictive potential of NLRC5 expression in cancer subsets.

4. Is the predictive potential of NLRC5 influenced by the mutational load and the frequency of neoantigen generation of different cancers?

5. Is NLRC5 essential or dispensable for tumor immune surveillance? Even though NLRC5 overexpression enhances tumor immunogenicity, whether NLRC5-independent MHC-I expression is sufficient for cancer immunosurveillance has not been yet experimentally addressed.

6. Does MHC-Ib expression in somatic cells require NLRC5? Does this impact NK cell-mediated cancer immune surveillance?

7. Irradiation of cancer cells induces NLRC5 expression. Does it require radiationinduced type-I IFN or not? If it occurs independently then what are the underlying mechanisms? Is the immunogenic cell death caused by irradiation depends on NLRC5? Can radiation induced NLRC 5 can be tuned to allow for improved antigen presentation before tumor cell death?

8. To what extent the size of NLRC5 required for its transactivation of MHC-I and APM genes be minimized to facilitate its translational potential for cancer immunotherapy and cancer antigen discovery?

Funding: This work is supported by the Canadian Institutes of Health Research (Project grant \#PJT-153174 to S.I.).

Institutional Review Board Statement: Not applicable.

Informed Consent Statement: Not applicable.

Acknowledgments: Madanraj Appiya Santharam was supported by the 'Abdenour-Nabid MD' graduate fellowship of the Faculty of Medicine and Health Sciences, Universite de Sherbrooke. All illustrations were created using the BioRender platform (Biorender.com).

Conflicts of Interest: The authors declare no conflict of interest.

\section{References}

1. Dunn, G.P.; Old, L.J.; Schreiber, R.D. The immunobiology of cancer immunosurveillance and immunoediting. Immunity 2004, 21, 137-148. [CrossRef]

2. Hanahan, D.; Weinberg, R.A. Hallmarks of cancer: The next generation. Cell 2011, 144, 646-674. [CrossRef] [PubMed]

3. Couzin-Frankel, J. Cancer Immunotherapy. Science 2013, 342, 1432-1433. [CrossRef]

4. Ledford, H.; Else, H.; Warren, M. Cancer immunologists scoop medicine Nobel prize. Nature 2018, 562, 20-21. [CrossRef]

5. Coley, W.B. The treatment of malignant tumors by repeated inoculations of erysipelas. With a report of ten original cases. 1893. Clin. Orthop. Relat. Res. 1991, 3-11. [PubMed]

6. Lenis, A.T.; Lec, P.M.; Chamie, K.; Mshs, M.D. Bladder Cancer: A Review. JAMA 2020, 324, 1980-1991. [CrossRef] 
7. Pettenati, C.; Ingersoll, M.A. Mechanisms of BCG immunotherapy and its outlook for bladder cancer. Nat. Rev. Urol. 2018, 15, 615-625. [CrossRef] [PubMed]

8. Thomas, L. On immunosurveillance in human cancer. Yale J. Biol. Med. 1982, 55, 329-333. [PubMed]

9. Shankaran, V.; Ikeda, H.; Bruce, A.T.; White, J.M.; Swanson, P.E.; Old, L.J.; Schreiber, R.D. IFNgamma and lymphocytes prevent primary tumour development and shape tumour immunogenicity. Nature 2001, 410, 1107-1111. [CrossRef]

10. Atkins, M.B.; Lotze, M.T.; Dutcher, J.P.; Fisher, R.I.; Weiss, G.; Margolin, K.; Abrams, J.; Sznol, M.; Parkinson, D.; Hawkins, M.; et al. High-dose recombinant interleukin 2 therapy for patients with metastatic melanoma: Analysis of 270 patients treated between 1985 and 1993. J. Clin. Oncol. 1999, 17, 2105-2116. [CrossRef]

11. Rosenberg, S.A.; Restifo, N.P.; Yang, J.C.; Morgan, R.A.; Dudley, M.E. Adoptive cell transfer: A clinical path to effective cancer immunotherapy. Nat. Rev. Cancer 2008, 8, 299-308. [CrossRef]

12. Fishman, M.; Dutcher, J.P.; Clark, J.I.; Alva, A.; Miletello, G.P.; Curti, B.; Agarwal, N.; Hauke, R.; Mahoney, K.M.; Moon, H.; et al. Overall survival by clinical risk category for high dose interleukin-2 (HD IL-2) treated patients with metastatic renal cell cancer (mRCC): Data from the PROCLAIM(SM) registry. J. Immunother. Cancer 2019, 7, 84. [CrossRef]

13. Rohaan, M.W.; Wilgenhof, S.; Haanen, J. Adoptive cellular therapies: The current landscape. Virchows Arch. 2019, 474, 449-461. [CrossRef] [PubMed]

14. Pardoll, D. Does the immune system see tumors as foreign or self? Annu. Rev. Immunol. 2003, 21, 807-839. [CrossRef]

15. Dunn, G.P.; Bruce, A.T.; Ikeda, H.; Old, L.J.; Schreiber, R.D. Cancer immunoediting: From immunosurveillance to tumor escape. Nat. Immunol. 2002, 3, 991-998. [CrossRef] [PubMed]

16. Ochsenbein, A.F.; Sierro, S.; Odermatt, B.; Pericin, M.; Karrer, U.; Hermans, J.; Hemmi, S.; Hengartner, H.; Zinkernagel, R.M. Roles of tumour localization, second signals and cross priming in cytotoxic T-cell induction. Nature 2001, 411, 1058-1064. [CrossRef] [PubMed]

17. Pardoll, D. T cells and tumours. Nature 2001, 411, 1010-1012. [CrossRef]

18. Zou, W. Immunosuppressive networks in the tumour environment and their therapeutic relevance. Nat. Rev. Cancer 2005, 5, 263-274. [CrossRef]

19. Fearon, D.T. Immune-Suppressing Cellular Elements of the Tumor Microenvironment. Annu. Rev. Cancer Biol. 2017, 1, 241-255. [CrossRef]

20. Spranger, S.; Gajewski, T.F. Mechanisms of Tumor Cell-Intrinsic Immune Evasion. Annu. Rev. Cancer Biol. 2018, 2, 213-228. [CrossRef]

21. Chen, D.S.; Mellman, I. Oncology meets immunology: The cancer-immunity cycle. Immunity 2013, 39, 1-10. [CrossRef] [PubMed]

22. Hicklin, D.J.; Marincola, F.M.; Ferrone, S. HLA class I antigen downregulation in human cancers: T-cell immunotherapy revives an old story. Mol. Med. Today 1999, 5, 178-186. [CrossRef]

23. Garrido, F.; Algarra, I.; Garcia-Lora, A.M. The escape of cancer from T lymphocytes: Immunoselection of MHC class I loss variants harboring structural-irreversible "hard" lesions. Cancer Immunol. Immunother. CII 2010, 59, 1601-1606. [CrossRef] [PubMed]

24. Garrido, F.; Aptsiauri, N.; Doorduijn, E.M.; Garcia Lora, A.M.; van Hall, T. The urgent need to recover MHC class I in cancers for effective immunotherapy. Curr. Opin. Immunol. 2016, 39, 44-51. [CrossRef]

25. Lampen, M.H.; van Hall, T. Strategies to counteract MHC-I defects in tumors. Curr. Opin. Immunol. 2011, 23, 293-298. [CrossRef]

26. Meissner, T.B.; Liu, Y.J.; Lee, K.H.; Li, A.; Biswas, A.; van Eggermond, M.C.; van den Elsen, P.J.; Kobayashi, K.S. NLRC5 cooperates with the RFX transcription factor complex to induce MHC class I gene expression. J. Immunol. 2012, 188, 4951-4958. [CrossRef] [PubMed]

27. Kobayashi, K.S.; van den Elsen, P.J. NLRC5: A key regulator of MHC class I-dependent immune responses. Nat. Rev. Immunol. 2012, 12, 813-820. [CrossRef]

28. Yoshihama, S.; Roszik, J.; Downs, I.; Meissner, T.B.; Vijayan, S.; Chapuy, B.; Sidiq, T.; Shipp, M.A.; Lizee, G.A.; Kobayashi, K.S. NLRC5/MHC class I transactivator is a target for immune evasion in cancer. Proc. Natl. Acad. Sci. USA 2016, 113, 5999-6004. [CrossRef]

29. Rodriguez, G.M.; Bobbala, D.; Serrano, D.; Mayhue, M.; Champagne, A.; Saucier, C.; Steimle, V.; Kufer, T.A.; Menendez, A.; Ramanathan, S.; et al. NLRC5 elicits antitumor immunity by enhancing processing and presentation of tumor antigens to CD8(+) T lymphocytes. Oncoimmunology 2016, 5, e1151593. [CrossRef]

30. Gross, L. Intradermal Immunization of $\mathrm{C} 3 \mathrm{H}$ Mice against a Sarcoma That Originated in an Animal of the Same Line. Cancer Res. 1943, 3, 326-333.

31. Delorme, E.J.; Alexander, P. Treatment of Primary Fibrosarcoma in the Rat with Immune Lymphocytes. Lancet 1964, 2, 117-120. [CrossRef]

32. Cheever, M.A.; Greenberg, P.D.; Fefer, A. Tumor neutralization, immunotherapy, and chemoimmunotherapy of a Friend leukemia with cells secondarily sensitized in vitro: II. Comparison of cells cultured with and without tumor to noncultured immune cells. J. Immunol. 1978, 121, 2220-2227.

33. Eberlein, T.J.; Rosenstein, M.; Rosenberg, S.A. Regression of a disseminated syngeneic solid tumor by systemic transfer of lymphoid cells expanded in interleukin 2. J. Exp. Med. 1982, 156, 385-397. [CrossRef] [PubMed]

34. Gansbacher, B.; Bannerji, R.; Daniels, B.; Zier, K.; Cronin, K.; Gilboa, E. Retroviral vector-mediated gamma-interferon gene transfer into tumor cells generates potent and long lasting antitumor immunity. Cancer Res. 1990, 50, 7820-7825. [PubMed] 
35. Townsend, S.E.; Allison, J.P. Tumor rejection after direct costimulation of CD8+ T cells by B7-transfected melanoma cells. Science 1993, 259, 368-370. [CrossRef] [PubMed]

36. Dranoff, G.; Jaffee, E.; Lazenby, A.; Golumbek, P.; Levitsky, H.; Brose, K.; Jackson, V.; Hamada, H.; Pardoll, D.; Mulligan, R.C. Vaccination with irradiated tumor cells engineered to secrete murine granulocyte-macrophage colony-stimulating factor stimulates potent, specific, and long-lasting anti-tumor immunity. Proc. Natl. Acad. Sci. USA 1993, 90, 3539-3543. [CrossRef]

37. Hock, H.; Dorsch, M.; Kunzendorf, U.; Qin, Z.; Diamantstein, T.; Blankenstein, T. Mechanisms of rejection induced by tumor cell-targeted gene transfer of interleukin 2, interleukin 4, interleukin 7, tumor necrosis factor, or interferon gamma. Proc. Natl. Acad. Sci. USA 1993, 90, 2774-2778. [CrossRef]

38. Knuth, A.; Danowski, B.; Oettgen, H.F.; Old, L.J. T-cell-mediated cytotoxicity against autologous malignant melanoma: Analysis with interleukin 2-dependent T-cell cultures. Proc. Natl. Acad. Sci. USA 1984, 81, 3511-3515. [CrossRef] [PubMed]

39. Degiovanni, G.; Lahaye, T.; Herin, M.; Hainaut, P.; Boon, T. Antigenic heterogeneity of a human melanoma tumor detected by autologous CTL clones. Eur. J. Immunol. 1988, 18, 671-676. [CrossRef]

40. Topalian, S.L.; Kasid, A.; Rosenberg, S.A. Immunoselection of a human melanoma resistant to specific lysis by autologous tumor-infiltrating lymphocytes. Possible mechanisms for immunotherapeutic failures. J. Immunol. 1990, 144, 4487-4495.

41. Tanaka, Y.; Tevethia, M.J.; Kalderon, D.; Smith, A.E.; Tevethia, S.S. Clustering of antigenic sites recognized by cytotoxic T lymphocyte clones in the amino terminal half of SV40 T antigen. Virology 1988, 162, 427-436. [CrossRef]

42. Klarnet, J.P.; Kern, D.E.; Okuno, K.; Holt, C.; Lilly, F.; Greenberg, P.D. FBL-reactive CD8+ cytotoxic and CD4+ helper T lymphocytes recognize distinct Friend murine leukemia virus-encoded antigens. J. Exp. Med. 1989, 169, 457-467. [CrossRef]

43. Kast, W.M.; Melief, C.J. Fine peptide specificity of cytotoxic T lymphocytes directed against adenovirus-induced tumours and peptide-MHC binding. Int. J. Cancer Suppl. 1991, 6, 90-94. [CrossRef]

44. Darrow, T.L.; Slingluff, C.L., Jr.; Seigler, H.F. The role of HLA class I antigens in recognition of melanoma cells by tumor-specific cytotoxic T lymphocytes. Evidence for shared tumor antigens. J. Immunol. 1989, 142, 3329-3335. [PubMed]

45. Kawakami, Y.; Zakut, R.; Topalian, S.L.; Stotter, H.; Rosenberg, S.A. Shared human melanoma antigens. Recognition by tumor-infiltrating lymphocytes in HLA-A2.1-transfected melanomas. J. Immunol. 1992, 148, 638-643. [PubMed]

46. Boon, T.; Cerottini, J.C.; Van den Eynde, B.; van der Bruggen, P.; Van Pel, A. Tumor antigens recognized by T lymphocytes. Annu. Rev. Immunol. 1994, 12, 337-365. [CrossRef] [PubMed]

47. Van der Bruggen, P.; Traversari, C.; Chomez, P.; Lurquin, C.; De Plaen, E.; Van den Eynde, B.; Knuth, A.; Boon, T. A gene encoding an antigen recognized by cytolytic T lymphocytes on a human melanoma. Science 1991, 254, 1643-1647. [CrossRef]

48. Van den Eynde, B.; Lethe, B.; Van Pel, A.; De Plaen, E.; Boon, T. The gene coding for a major tumor rejection antigen of tumor P815 is identical to the normal gene of syngeneic DBA/2 mice. J. Exp. Med. 1991, 173, 1373-1384. [CrossRef] [PubMed]

49. Traversari, C.; van der Bruggen, P.; Van den Eynde, B.; Hainaut, P.; Lemoine, C.; Ohta, N.; Old, L.; Boon, T. Transfection and expression of a gene coding for a human melanoma antigen recognized by autologous cytolytic T lymphocytes. Immunogenetics 1992, 35, 145-152. [CrossRef]

50. Jerome, K.R.; Domenech, N.; Finn, O.J. Tumor-specific cytotoxic T cell clones from patients with breast and pancreatic adenocarcinoma recognize EBV-immortalized B cells transfected with polymorphic epithelial mucin complementary DNA. J. Immunol. 1993, $151,1654-1662$.

51. Van Bleek, G.M.; Nathenson, S.G. Isolation of an endogenously processed immunodominant viral peptide from the class I H-2Kb molecule. Nature 1990, 348, 213-216. [CrossRef]

52. Falk, K.; Rotzschke, O.; Rammensee, H.G. Cellular peptide composition governed by major histocompatibility complex class I molecules. Nature 1990, 348, 248-251. [CrossRef] [PubMed]

53. Wallny, H.J.; Deres, K.; Faath, S.; Jung, G.; Van Pel, A.; Boon, T.; Rammensee, H.G. Identification and quantification of a naturally presented peptide as recognized by cytotoxic T lymphocytes specific for an immunogenic tumor variant. Int. Immunol. 1992, 4 , 1085-1090. [CrossRef]

54. Slingluff, C.L., Jr.; Cox, A.L.; Henderson, R.A.; Hunt, D.F.; Engelhard, V.H. Recognition of human melanoma cells by HLA-A2.1restricted cytotoxic T lymphocytes is mediated by at least six shared peptide epitopes. J. Immunol. 1993, 150, $2955-2963$.

55. Coulie, P.G.; Van den Eynde, B.J.; van der Bruggen, P.; Boon, T. Tumour antigens recognized by T lymphocytes: At the core of cancer immunotherapy. Nat. Rev. Cancer 2014, 14, 135-146. [CrossRef]

56. Schumacher, T.N.; Schreiber, R.D. Neoantigens in cancer immunotherapy. Science 2015, 348, 69-74. [CrossRef] [PubMed]

57. Snyder, A.; Chan, T.A. Immunogenic peptide discovery in cancer genomes. Curr. Opin. Genet. Dev. 2015, 30, 7-16. [CrossRef] [PubMed]

58. Yewdell, J.W. Plumbing the sources of endogenous MHC class I peptide ligands. Curr. Opin. Immunol. 2007, 19, 79-86. [CrossRef]

59. Granados, D.P.; Laumont, C.M.; Thibault, P.; Perreault, C. The nature of self for T cells-a systems-level perspective. Curr. Opin. Immunol. 2015, 34, 1-8. [CrossRef]

60. Laumont, C.M.; Daouda, T.; Laverdure, J.P.; Bonneil, E.; Caron-Lizotte, O.; Hardy, M.P.; Granados, D.P.; Durette, C.; Lemieux, S.; Thibault, P.; et al. Global proteogenomic analysis of human MHC class I-associated peptides derived from non-canonical reading frames. Nat. Commun. 2016, 7, 10238. [CrossRef]

61. Shao, W.; Pedrioli, P.G.A.; Wolski, W.; Scurtescu, C.; Schmid, E.; Vizcaino, J.A.; Courcelles, M.; Schuster, H.; Kowalewski, D.; Marino, F.; et al. The SysteMHC Atlas project. Nucleic Acids Res. 2018, 46, D1237-D1247. [CrossRef] 
62. Zhao, Q.; Laverdure, J.P.; Lanoix, J.; Durette, C.; Cote, C.; Bonneil, E.; Laumont, C.M.; Gendron, P.; Vincent, K.; Courcelles, M.; et al. Proteogenomics Uncovers a Vast Repertoire of Shared Tumor-Specific Antigens in Ovarian Cancer. Cancer Immunol. Res. 2020, 8, 544-555. [CrossRef] [PubMed]

63. Ebstein, F.; Textoris-Taube, K.; Keller, C.; Golnik, R.; Vigneron, N.; Van den Eynde, B.J.; Schuler-Thurner, B.; Schadendorf, D.; Lorenz, F.K.; Uckert, W.; et al. Proteasomes generate spliced epitopes by two different mechanisms and as efficiently as non-spliced epitopes. Sci. Rep. 2016, 6, 24032. [CrossRef] [PubMed]

64. Liepe, J.; Marino, F.; Sidney, J.; Jeko, A.; Bunting, D.E.; Sette, A.; Kloetzel, P.M.; Stumpf, M.P.; Heck, A.J.; Mishto, M. A large fraction of HLA class I ligands are proteasome-generated spliced peptides. Science 2016, 354, 354-358. [CrossRef] [PubMed]

65. Anton, L.C.; Yewdell, J.W. Translating DRiPs: MHC class I immunosurveillance of pathogens and tumors. J. Leukoc. Biol. 2014, 95, 551-562. [CrossRef] [PubMed]

66. Platteel, A.C.M.; Liepe, J.; van Eden, W.; Mishto, M.; Sijts, A. An Unexpected Major Role for Proteasome-Catalyzed Peptide Splicing in Generation of T Cell Epitopes: Is There Relevance for Vaccine Development? Front. Immunol. 2017, 8, 1441. [CrossRef]

67. Rolfs, Z.; Solntsev, S.K.; Shortreed, M.R.; Frey, B.L.; Smith, L.M. Global Identification of Post-Translationally Spliced Peptides with Neo-Fusion. J. Proteome Res. 2019, 18, 349-358. [CrossRef]

68. Germain, R.N. MHC-dependent antigen processing and peptide presentation: Providing ligands for T lymphocyte activation. Cell 1994, 76, 287-299. [CrossRef]

69. Vyas, J.M.; Van der Veen, A.G.; Ploegh, H.L. The known unknowns of antigen processing and presentation. Nat. Rev. Immunol. 2008, 8, 607-618. [CrossRef]

70. Neefjes, J.; Jongsma, M.L.; Paul, P.; Bakke, O. Towards a systems understanding of MHC class I and MHC class II antigen presentation. Nat. Rev. Immunol. 2011, 11, 823-836. [CrossRef]

71. Linsley, P.S.; Ledbetter, J.A. The role of the CD28 receptor during T cell responses to antigen. Annu. Rev. Immunol. 1993, 11, 191-212. [CrossRef]

72. Lenschow, D.J.; Walunas, T.L.; Bluestone, J.A. CD28/B7 system of T cell costimulation. Annu. Rev. Immunol. 1996, 14, 233-258. [CrossRef] [PubMed]

73. Hoffmann, T.K.; Meidenbauer, N.; Dworacki, G.; Kanaya, H.; Whiteside, T.L. Generation of tumor-specific T-lymphocytes by cross-priming with human dendritic cells ingesting apoptotic tumor cells. Cancer Res. 2000, 60, 3542-3549.

74. Den Haan, J.M.; Bevan, M.J. Antigen presentation to CD8+ T cells: Cross-priming in infectious diseases. Curr. Opin. Immunol. 2001, 13, 437-441. [CrossRef]

75. Yatim, N.; Cullen, S.; Albert, M.L. Dying cells actively regulate adaptive immune responses. Nat. Rev. Immunol. 2017, 17, 262-275 [CrossRef] [PubMed]

76. Amm, I.; Sommer, T.; Wolf, D.H. Protein quality control and elimination of protein waste: The role of the ubiquitin-proteasome system. Biochim. Biophys. Acta 2014, 1843, 182-196. [CrossRef] [PubMed]

77. Kloetzel, P.M. Antigen processing by the proteasome. Nat. Rev. Mol. Cell Biol. 2001, 2, 179-187. [CrossRef] [PubMed]

78. Tanaka, K. The proteasome: Overview of structure and functions. Proc. Jpn. Acad. Ser. B Phys. Biol. Sci. 2009, 85, 12-36. [CrossRef] [PubMed]

79. Yewdell, J.W.; Reits, E.; Neefjes, J. Making sense of mass destruction: Quantitating MHC class I antigen presentation. Nat. Rev. Immunol. 2003, 3, 952-961. [CrossRef] [PubMed]

80. Eggensperger, S.; Tampe, R. The transporter associated with antigen processing: A key player in adaptive immunity. Biol. Chem. 2015, 396, 1059-1072. [CrossRef]

81. Hulpke, S.; Tampe, R. The MHC I loading complex: A multitasking machinery in adaptive immunity. Trends Biochem. Sci. 2013, 38, 412-420. [CrossRef]

82. Kloetzel, P.M. The proteasome and MHC class I antigen processing. Biochim. Biophys. Acta 2004, 1695, 225-233. [CrossRef]

83. Abarca-Heidemann, K.; Friederichs, S.; Klamp, T.; Boehm, U.; Guethlein, L.A.; Ortmann, B. Regulation of the expression of mouse TAP-associated glycoprotein (tapasin) by cytokines. Immunol. Lett. 2002, 83, 197-207. [CrossRef]

84. Seliger, B.; Ruiz-Cabello, F.; Garrido, F. IFN inducibility of major histocompatibility antigens in tumors. Adv. Cancer Res. 2008, 101, 249-276. [CrossRef]

85. Abdel-Wahab, Z.; Dar, M.M.; Hester, D.; Vervaert, C.; Gangavalli, R.; Barber, J.; Darrow, T.L.; Seigler, H.F. Effect of irradiation on cytokine production, MHC antigen expression, and vaccine potential of interleukin-2 and interferon-gamma gene-modified melanoma cells. Cell. Immunol. 1996, 171, 246-254. [CrossRef] [PubMed]

86. Seliger, B.; Wollscheid, U.; Momburg, F.; Blankenstein, T.; Huber, C. Characterization of the major histocompatibility complex class I deficiencies in B16 melanoma cells. Cancer Res. 2001, 61, 1095-1099. [PubMed]

87. Joyce, J.A.; Fearon, D.T. T cell exclusion, immune privilege, and the tumor microenvironment. Science 2015, 348, 74-80. [CrossRef] [PubMed]

88. Pardoll, D.M. The blockade of immune checkpoints in cancer immunotherapy. Nat. Rev. Cancer 2012, 12, 252-264. [CrossRef]

89. Clouthier, D.L.; Ohashi, P.S. Costimulation, a surprising connection for immunotherapy. Science 2017, 355, 1373-1374. [CrossRef]

90. Garcia-Lora, A.; Algarra, I.; Garrido, F. MHC class I antigens, immune surveillance, and tumor immune escape. J. Cell. Physiol. 2003, 195, 346-355. [CrossRef]

91. Bukur, J.; Jasinski, S.; Seliger, B. The role of classical and non-classical HLA class I antigens in human tumors. Semin. Cancer Biol. 2012, 22, 350-358. [CrossRef] 
92. Parham, P.; Lomen, C.E.; Lawlor, D.A.; Ways, J.P.; Holmes, N.; Coppin, H.L.; Salter, R.D.; Wan, A.M.; Ennis, P.D. Nature of polymorphism in HLA-A, -B, and -C molecules. Proc. Natl. Acad. Sci. USA 1988, 85, 4005-4009. [CrossRef]

93. Bjorkman, P.J.; Parham, P. Structure, function, and diversity of class I major histocompatibility complex molecules. Annu. Rev. Biochem. 1990, 59, 253-288. [CrossRef]

94. Shawar, S.M.; Vyas, J.M.; Rodgers, J.R.; Rich, R.R. Antigen presentation by major histocompatibility complex class I-B molecules. Annu. Rev. Immunol. 1994, 12, 839-880. [CrossRef] [PubMed]

95. D'Souza, M.P.; Adams, E.; Altman, J.D.; Birnbaum, M.E.; Boggiano, C.; Casorati, G.; Chien, Y.H.; Conley, A.; Eckle, S.B.G.; Fruh, K.; et al. Casting a wider net: Immunosurveillance by nonclassical MHC molecules. PLoS Pathog. 2019, 15, e1007567. [CrossRef]

96. Koopman, L.A.; Corver, W.E.; van der Slik, A.R.; Giphart, M.J.; Fleuren, G.J. Multiple genetic alterations cause frequent and heterogeneous human histocompatibility leukocyte antigen class I loss in cervical cancer. J. Exp. Med. 2000, 191, 961-976. [CrossRef]

97. Paschen, A.; Mendez, R.M.; Jimenez, P.; Sucker, A.; Ruiz-Cabello, F.; Song, M.; Garrido, F.; Schadendorf, D. Complete loss of HLA class I antigen expression on melanoma cells: A result of successive mutational events. Int. J. Cancer. 2003, 103, $759-767$. [CrossRef] [PubMed]

98. Seliger, B.; Maeurer, M.J.; Ferrone, S. TAP off-Tumors on. Immunol. Today 1997, 18, 292-299. [CrossRef]

99. Benitez, R.; Godelaine, D.; Lopez-Nevot, M.A.; Brasseur, F.; Jimenez, P.; Marchand, M.; Oliva, M.R.; van Baren, N.; Cabrera, T.; Andry, G.; et al. Mutations of the beta2-microglobulin gene result in a lack of HLA class I molecules on melanoma cells of two patients immunized with MAGE peptides. Tissue Antigens 1998, 52, 520-529. [CrossRef] [PubMed]

100. Leone, P.; Shin, E.C.; Perosa, F.; Vacca, A.; Dammacco, F.; Racanelli, V. MHC class I antigen processing and presenting machinery: Organization, function, and defects in tumor cells. J. Natl. Cancer Inst. 2013, 105, 1172-1187. [CrossRef]

101. Chen, H.L.; Gabrilovich, D.; Tampe, R.; Girgis, K.R.; Nadaf, S.; Carbone, D.P. A functionally defective allele of TAP1 results in loss of MHC class I antigen presentation in a human lung cancer. Nat. Genet. 1996, 13, 210-213. [CrossRef]

102. Seliger, B.; Ritz, U.; Abele, R.; Bock, M.; Tampe, R.; Sutter, G.; Drexler, I.; Huber, C.; Ferrone, S. Immune escape of melanoma: First evidence of structural alterations in two distinct components of the MHC class I antigen processing pathway. Cancer Res. 2001, $61,8647-8650$.

103. Sokol, L.; Koelzer, V.H.; Rau, T.T.; Karamitopoulou, E.; Zlobec, I.; Lugli, A. Loss of tapasin correlates with diminished CD8(+) T-cell immunity and prognosis in colorectal cancer. J. Transl. Med. 2015, 13, 279. [CrossRef]

104. Rodriguez, T.; Mendez, R.; Del Campo, A.; Jimenez, P.; Aptsiauri, N.; Garrido, F.; Ruiz-Cabello, F. Distinct mechanisms of loss of IFN-gamma mediated HLA class I inducibility in two melanoma cell lines. BMC Cancer 2007, 7, 34. [CrossRef]

105. Respa, A.; Bukur, J.; Ferrone, S.; Pawelec, G.; Zhao, Y.; Wang, E.; Marincola, F.M.; Seliger, B. Association of IFN-gamma signal transduction defects with impaired HLA class I antigen processing in melanoma cell lines. Clin. Cancer Res. Off. J. Am. Assoc. Cancer Res. 2011, 17, 2668-2678. [CrossRef] [PubMed]

106. Campoli, M.; Chang, C.C.; Ferrone, S. HLA class I antigen loss, tumor immune escape and immune selection. Vaccine 2002, 20 (Suppl. 4), A40-A45. [CrossRef]

107. Cabrera, T.; Lara, E.; Romero, J.M.; Maleno, I.; Real, L.M.; Ruiz-Cabello, F.; Valero, P.; Camacho, F.M.; Garrido, F. HLA class I expression in metastatic melanoma correlates with tumor development during autologous vaccination. Cancer Immunol. Immunother. CII 2007, 56, 709-717. [CrossRef]

108. Carretero, R.; Romero, J.M.; Ruiz-Cabello, F.; Maleno, I.; Rodriguez, F.; Camacho, F.M.; Real, L.M.; Garrido, F.; Cabrera, T. Analysis of HLA class I expression in progressing and regressing metastatic melanoma lesions after immunotherapy. Immunogenetics 2008, 60, 439-447. [CrossRef] [PubMed]

109. Seliger, B. Molecular mechanisms of MHC class I abnormalities and APM components in human tumors. Cancer Immunol. Immunother. CII 2008, 57, 1719-1726. [CrossRef]

110. Garrido, F.; Cabrera, T.; Aptsiauri, N. "Hard" and "soft" lesions underlying the HLA class I alterations in cancer cells: Implications for immunotherapy. Int. J. Cancer. 2010, 127, 249-256. [CrossRef]

111. Nie, Y.; Yang, G.; Song, Y.; Zhao, X.; So, C.; Liao, J.; Wang, L.D.; Yang, C.S. DNA hypermethylation is a mechanism for loss of expression of the HLA class I genes in human esophageal squamous cell carcinomas. Carcinogenesis 2001, 22, 1615-1623. [CrossRef] [PubMed]

112. Sigalotti, L.; Fratta, E.; Coral, S.; Tanzarella, S.; Danielli, R.; Colizzi, F.; Fonsatti, E.; Traversari, C.; Altomonte, M.; Maio, M. Intratumor heterogeneity of cancer/testis antigens expression in human cutaneous melanoma is methylation-regulated and functionally reverted by 5-aza-2'-deoxycytidine. Cancer Res. 2004, 64, 9167-9171. [CrossRef]

113. Manning, J.; Indrova, M.; Lubyova, B.; Pribylova, H.; Bieblova, J.; Hejnar, J.; Simova, J.; Jandlova, T.; Bubenik, J.; Reinis, M. Induction of MHC class I molecule cell surface expression and epigenetic activation of antigen-processing machinery components in a murine model for human papilloma virus 16-associated tumours. Immunology 2008, 123, 218-227. [CrossRef]

114. Campoli, M.; Ferrone, S. HLA antigen changes in malignant cells: Epigenetic mechanisms and biologic significance. Oncogene 2008, 27, 5869-5885. [CrossRef]

115. Khan, A.N.; Gregorie, C.J.; Tomasi, T.B. Histone deacetylase inhibitors induce TAP, LMP, Tapasin genes and MHC class I antigen presentation by melanoma cells. Cancer Immunol. Immunother. CII 2008, 57, 647-654. [CrossRef] [PubMed] 
116. Setiadi, A.F.; Omilusik, K.; David, M.D.; Seipp, R.P.; Hartikainen, J.; Gopaul, R.; Choi, K.B.; Jefferies, W.A. Epigenetic enhancement of antigen processing and presentation promotes immune recognition of tumors. Cancer Res. 2008, 68, 9601-9607. [CrossRef] [PubMed]

117. Vlkova, V.; Stepanek, I.; Hruskova, V.; Senigl, F.; Mayerova, V.; Sramek, M.; Simova, J.; Bieblova, J.; Indrova, M.; Hejhal, T.; et al. Epigenetic regulations in the IFNgamma signalling pathway: IFNgamma-mediated MHC class I upregulation on tumour cells is associated with DNA demethylation of antigen-presenting machinery genes. Oncotarget 2014, 5, 6923-6935. [CrossRef] [PubMed]

118. Li, H.; Chiappinelli, K.B.; Guzzetta, A.A.; Easwaran, H.; Yen, R.W.; Vatapalli, R.; Topper, M.J.; Luo, J.; Connolly, R.M.; Azad, N.S.; et al. Immune regulation by low doses of the DNA methyltransferase inhibitor 5-azacitidine in common human epithelial cancers. Oncotarget 2014, 5, 587-598. [CrossRef] [PubMed]

119. Coscoy, L.; Ganem, D. Kaposi's sarcoma-associated herpesvirus encodes two proteins that block cell surface display of MHC class I chains by enhancing their endocytosis. Proc. Natl. Acad. Sci. USA 2000, 97, 8051-8056. [CrossRef]

120. Ishido, S.; Wang, C.; Lee, B.S.; Cohen, G.B.; Jung, J.U. Downregulation of major histocompatibility complex class I molecules by Kaposi's sarcoma-associated herpesvirus K3 and K5 proteins. J. Virol. 2000, 74, 5300-5309. [CrossRef]

121. Stevenson, P.G.; Efstathiou, S.; Doherty, P.C.; Lehner, P.J. Inhibition of MHC class I-restricted antigen presentation by gamma 2-herpesviruses. Proc. Natl. Acad. Sci. USA 2000, 97, 8455-8460. [CrossRef]

122. Bartee, E.; Mansouri, M.; Hovey Nerenberg, B.T.; Gouveia, K.; Fruh, K. Downregulation of major histocompatibility complex class I by human ubiquitin ligases related to viral immune evasion proteins. J. Virol. 2004, 78, 1109-1120. [CrossRef] [PubMed]

123. Boname, J.M.; Thomas, M.; Stagg, H.R.; Xu, P.; Peng, J.; Lehner, P.J. Efficient internalization of MHC I requires lysine-11 and lysine-63 mixed linkage polyubiquitin chains. Traffic 2010, 11, 210-220. [CrossRef] [PubMed]

124. Duncan, L.M.; Nathan, J.A.; Lehner, P.J. Stabilization of an E3 ligase-E2-ubiquitin complex increases cell surface MHC class I expression. J. Immunol. 2010, 184, 6978-6985. [CrossRef]

125. Lin, H.; Li, S.; Shu, H.B. The Membrane-Associated MARCH E3 Ligase Family: Emerging Roles in Immune Regulation. Front. Immunol. 2019, 10, 1751. [CrossRef]

126. De Angelis Rigotti, F.; De Gassart, A.; Pforr, C.; Cano, F.; N’Guessan, P.; Combes, A.; Camossetto, V.; Lehner, P.J.; Pierre, P.; Gatti, E. MARCH9-mediated ubiquitination regulates MHC I export from the TGN. Immunol. Cell Biol. 2017, 95, 753-764. [CrossRef] [PubMed]

127. El-Jawhari, J.J.; El-Sherbiny, Y.M.; Scott, G.B.; Morgan, R.S.; Prestwich, R.; Bowles, P.A.; Blair, G.E.; Tanaka, T.; Rabbitts, T.H.; Meade, J.L.; et al. Blocking oncogenic RAS enhances tumour cell surface MHC class I expression but does not alter susceptibility to cytotoxic lymphocytes. Mol. Immunol. 2014, 58, 160-168. [CrossRef]

128. Yamamoto, K.; Venida, A.; Yano, J.; Biancur, D.E.; Kakiuchi, M.; Gupta, S.; Sohn, A.S.W.; Mukhopadhyay, S.; Lin, E.Y.; Parker, S.J.; et al. Autophagy promotes immune evasion of pancreatic cancer by degrading MHC-I. Nature 2020, 581, 100-105. [CrossRef] [PubMed]

129. Bear, A.S.; Vonderheide, R.H.; O’Hara, M.H. Challenges and Opportunities for Pancreatic Cancer Immunotherapy. Cancer Cell 2020, 38, 788-802. [CrossRef]

130. Meissner, T.B.; Li, A.; Biswas, A.; Lee, K.H.; Liu, Y.J.; Bayir, E.; Iliopoulos, D.; van den Elsen, P.J.; Kobayashi, K.S. NLR family member NLRC5 is a transcriptional regulator of MHC class I genes. Proc. Natl. Acad. Sci. USA 2010, 107, 13794-13799. [CrossRef]

131. Magalhaes, J.G.; Sorbara, M.T.; Girardin, S.E.; Philpott, D.J. What is new with Nods? Curr. Opin. Immunol. 2011, 23, 29-34. [CrossRef]

132. Motta, V.; Soares, F.; Sun, T.; Philpott, D.J. NOD-like receptors: Versatile cytosolic sentinels. Physiol. Rev. 2015, 95, 149-178. [CrossRef]

133. Steimle, V.; Otten, L.A.; Zufferey, M.; Mach, B. Complementation cloning of an MHC class II transactivator mutated in hereditary MHC class II deficiency (or bare lymphocyte syndrome). Cell 1993, 75, 135-146. [CrossRef]

134. Steimle, V.; Siegrist, C.A.; Mottet, A.; Lisowska-Grospierre, B.; Mach, B. Regulation of MHC class II expression by interferongamma mediated by the transactivator gene CIITA. Science 1994, 265, 106-109. [CrossRef]

135. Cui, J.; Zhu, L.; Xia, X.; Wang, H.Y.; Legras, X.; Hong, J.; Ji, J.; Shen, P.; Zheng, S.; Chen, Z.J.; et al. NLRC5 negatively regulates the NF-kappaB and type I interferon signaling pathways. Cell 2010, 141, 483-496. [CrossRef] [PubMed]

136. Benko, S.; Magalhaes, J.G.; Philpott, D.J.; Girardin, S.E. NLRC5 limits the activation of inflammatory pathways. J. Immunol. 2010, 185, 1681-1691. [CrossRef]

137. Neerincx, A.; Lautz, K.; Menning, M.; Kremmer, E.; Zigrino, P.; Hosel, M.; Buning, H.; Schwarzenbacher, R.; Kufer, T.A. A role for the human nucleotide-binding domain, leucine-rich repeat-containing family member NLRC5 in antiviral responses. J. Biol. Chem. 2010, 285, 26223-26232. [CrossRef] [PubMed]

138. Ranjan, P.; Singh, N.; Kumar, A.; Neerincx, A.; Kremmer, E.; Cao, W.; Davis, W.G.; Katz, J.M.; Gangappa, S.; Lin, R.; et al. NLRC5 interacts with RIG-I to induce a robust antiviral response against influenza virus infection. Eur. J. Immunol. 2015, 45, 758-772. [CrossRef]

139. Kumar, H.; Pandey, S.; Zou, J.; Kumagai, Y.; Takahashi, K.; Akira, S.; Kawai, T. NLRC5 deficiency does not influence cytokine induction by virus and bacteria infections. J. Immunol. 2011, 186, 994-1000. [CrossRef] [PubMed]

140. Robbins, G.R.; Truax, A.D.; Davis, B.K.; Zhang, L.; Brickey, W.J.; Ting, J.P. Regulation of class I major histocompatibility complex (MHC) by nucleotide-binding domain, leucine-rich repeat-containing (NLR) proteins. J. Biol. Chem. 2012, 287, 24294-24303. [CrossRef] 
141. Yao, Y.; Qian, Y. Expression regulation and function of NLRC5. Protein Cell 2013, 4, 168-175. [CrossRef]

142. Tong, Y.; Cui, J.; Li, Q.; Zou, J.; Wang, H.Y.; Wang, R.F. Enhanced TLR-induced NF-kappaB signaling and type I interferon responses in NLRC5 deficient mice. Cell Res. 2012, 22, 822-835. [CrossRef]

143. Chonwerawong, M.; Ferrand, J.; Chaudhry, H.M.; Higgins, C.; Tran, L.S.; Lim, S.S.; Walker, M.M.; Bhathal, P.S.; Dev, A.; Moore, G.T.; et al. Innate Immune Molecule NLRC5 Protects Mice from Helicobacter-induced Formation of Gastric Lymphoid Tissue. Gastroenterology 2020, 159, 169-182.e168. [CrossRef]

144. Benko, S.; Kovacs, E.G.; Hezel, F.; Kufer, T.A. NLRC5 Functions beyond MHC I Regulation-What Do We Know So Far? Front. Immunol. 2017, 8, 150. [CrossRef]

145. Davis, B.K.; Roberts, R.A.; Huang, M.T.; Willingham, S.B.; Conti, B.J.; Brickey, W.J.; Barker, B.R.; Kwan, M.; Taxman, D.J.; Accavitti-Loper, M.A.; et al. Cutting edge: NLRC5-dependent activation of the inflammasome. J. Immunol. 2011, 186, 1333-1337. [CrossRef]

146. Yao, Y.; Wang, Y.; Chen, F.; Huang, Y.; Zhu, S.; Leng, Q.; Wang, H.; Shi, Y.; Qian, Y. NLRC5 regulates MHC class I antigen presentation in host defense against intracellular pathogens. Cell Res. 2012, 22, 836-847. [CrossRef] [PubMed]

147. Triantafilou, K.; Kar, S.; van Kuppeveld, F.J.; Triantafilou, M. Rhinovirus-induced calcium flux triggers NLRP3 and NLRC5 activation in bronchial cells. Am. J. Respir. Cell Mol. Biol. 2013, 49, 923-934. [CrossRef] [PubMed]

148. Biswas, A.; Meissner, T.B.; Kawai, T.; Kobayashi, K.S. Cutting edge: Impaired MHC class I expression in mice deficient for Nlrc5/class I transactivator. J. Immunol. 2012, 189, 516-520. [CrossRef]

149. Staehli, F.; Ludigs, K.; Heinz, L.X.; Seguin-Estevez, Q.; Ferrero, I.; Braun, M.; Schroder, K.; Rebsamen, M.; Tardivel, A.; Mattmann, C.; et al. NLRC5 deficiency selectively impairs MHC class I- dependent lymphocyte killing by cytotoxic T cells. J. Immunol. 2012, 188, 3820-3828. [CrossRef]

150. Meissner, T.B.; Li, A.; Kobayashi, K.S. NLRC5: A newly discovered MHC class I transactivator (CITA). Microbes Infect. 2012, 14, 477-484. [CrossRef] [PubMed]

151. Kuenzel, S.; Till, A.; Winkler, M.; Hasler, R.; Lipinski, S.; Jung, S.; Grotzinger, J.; Fickenscher, H.; Schreiber, S.; Rosenstiel, P. The nucleotide-binding oligomerization domain-like receptor NLRC5 is involved in IFN-dependent antiviral immune responses. J. Immunol. 2010, 184, 1990-2000. [CrossRef]

152. Ng, A.C.; Eisenberg, J.M.; Heath, R.J.; Huett, A.; Robinson, C.M.; Nau, G.J.; Xavier, R.J. Human leucine-rich repeat proteins: A genome-wide bioinformatic categorization and functional analysis in innate immunity. Proc. Natl. Acad. Sci. USA 2011, 108 (Suppl. 1), 4631-4638. [CrossRef] [PubMed]

153. Gutte, P.G.; Jurt, S.; Grutter, M.G.; Zerbe, O. Unusual structural features revealed by the solution NMR structure of the NLRC5 caspase recruitment domain. Biochemistry 2014, 53, 3106-3117. [CrossRef] [PubMed]

154. Neerincx, A.; Rodriguez, G.M.; Steimle, V.; Kufer, T.A. NLRC5 controls basal MHC class I gene expression in an MHC enhanceosome-dependent manner. J. Immunol. 2012, 188, 4940-4950. [CrossRef] [PubMed]

155. Meissner, T.B.; Li, A.; Liu, Y.J.; Gagnon, E.; Kobayashi, K.S. The nucleotide-binding domain of NLRC5 is critical for nuclear import and transactivation activity. Biochem. Biophys. Res. Commun. 2012, 418, 786-791. [CrossRef] [PubMed]

156. Gobin, S.J.; van Zutphen, M.; Westerheide, S.D.; Boss, J.M.; van den Elsen, P.J. The MHC-specific enhanceosome and its role in MHC class I and beta(2)-microglobulin gene transactivation. J. Immunol. 2001, 167, 5175-5184. [CrossRef] [PubMed]

157. Van den Elsen, P.J. Expression regulation of major histocompatibility complex class I and class II encoding genes. Front. Immunol. 2011, 2, 48. [CrossRef]

158. Ludigs, K.; Seguin-Estevez, Q.; Lemeille, S.; Ferrero, I.; Rota, G.; Chelbi, S.; Mattmann, C.; MacDonald, H.R.; Reith, W.; Guarda, G. NLRC5 exclusively transactivates MHC class I and related genes through a distinctive SXY module. PLoS Genet. 2015, 11, e1005088. [CrossRef]

159. Gobin, S.J.; Peijnenburg, A.; Keijsers, V.; van den Elsen, P.J. Site alpha is crucial for two routes of IFN gamma-induced MHC class I transactivation: The ISRE-mediated route and a novel pathway involving CIITA. Immunity 1997, 6, 601-611. [CrossRef]

160. Martin, B.K.; Chin, K.C.; Olsen, J.C.; Skinner, C.A.; Dey, A.; Ozato, K.; Ting, J.P. Induction of MHC class I expression by the MHC class II transactivator CIITA. Immunity 1997, 6, 591-600. [CrossRef]

161. Hobart, M.; Ramassar, V.; Goes, N.; Urmson, J.; Halloran, P.F. IFN regulatory factor-1 plays a central role in the regulation of the expression of class I and II MHC genes in vivo. J. Immunol. 1997, 158, 4260-4269. [PubMed]

162. Gobin, S.J.; Keijsers, V.; van Zutphen, M.; van den Elsen, P.J. The role of enhancer A in the locus-specific transactivation of classical and nonclassical HLA class I genes by nuclear factor kappa B. J. Immunol. 1998, 161, 2276-2283.

163. Israel, A.; Le Bail, O.; Hatat, D.; Piette, J.; Kieran, M.; Logeat, F.; Wallach, D.; Fellous, M.; Kourilsky, P. TNF stimulates expression of mouse MHC class I genes by inducing an NF kappa B-like enhancer binding activity which displaces constitutive factors. EMBO J. 1989, 8, 3793-3800. [CrossRef]

164. Gobin, S.J.; van den Elsen, P.J. The regulation of HLA class I expression: Is HLA-G the odd one out? Semin. Cancer Biol. 1999, 9,55-59. [CrossRef] [PubMed]

165. Wright, K.L.; Ting, J.P. Epigenetic regulation of MHC-II and CIITA genes. Trends Immunol. 2006, 27, 405-412. [CrossRef]

166. Lupfer, C.R.; Stokes, K.L.; Kuriakose, T.; Kanneganti, T.D. Deficiency of the NOD-Like Receptor NLRC5 Results in Decreased CD8(+) T Cell Function and Impaired Viral Clearance. J. Virol. 2017, 91. [CrossRef]

167. Sun, T.; Ferrero, R.L.; Girardin, S.E.; Gommerman, J.L.; Philpott, D.J. NLRC5 deficiency has a moderate impact on immunodominant CD8(+) T cell responses during rotavirus infection of adult mice. Immunol. Cell Biol. 2019. [CrossRef] [PubMed] 
168. Chang, C.H.; Guerder, S.; Hong, S.C.; van Ewijk, W.; Flavell, R.A. Mice lacking the MHC class II transactivator (CIITA) show tissue-specific impairment of MHC class II expression. Immunity 1996, 4, 167-178. [CrossRef]

169. Williams, G.S.; Malin, M.; Vremec, D.; Chang, C.H.; Boyd, R.; Benoist, C.; Mathis, D. Mice lacking the transcription factor CIITA-a second look. Int. Immunol. 1998, 10, 1957-1967. [CrossRef] [PubMed]

170. Benhammadi, M.; Mathe, J.; Dumont-Lagace, M.; Kobayashi, K.S.; Gaboury, L.; Brochu, S.; Perreault, C. IFN-lambda Enhances Constitutive Expression of MHC Class I Molecules on Thymic Epithelial Cells. J. Immunol. 2020, 205, 1268-1280. [CrossRef]

171. Kobayashi, K.S. NLRC5/CITA: A novel regulator of class I major histocompatibility complex genes. J. Immunodefic. Disord. 2012, 1. [CrossRef]

172. Xu, H.C.; Grusdat, M.; Pandyra, A.A.; Polz, R.; Huang, J.; Sharma, P.; Deenen, R.; Kohrer, K.; Rahbar, R.; Diefenbach, A.; et al. Type I interferon protects antiviral CD8+ T cells from NK cell cytotoxicity. Immunity 2014, 40, 949-960. [CrossRef] [PubMed]

173. Ludigs, K.; Jandus, C.; Utzschneider, D.T.; Staehli, F.; Bessoles, S.; Dang, A.T.; Rota, G.; Castro, W.; Zehn, D.; Vivier, E.; et al. NLRC5 shields T lymphocytes from NK-cell-mediated elimination under inflammatory conditions. Nat. Commun. 2016, 7, 10554. [CrossRef] [PubMed]

174. Rota, G.; Ludigs, K.; Siegert, S.; Tardivel, A.; Morgado, L.; Reith, W.; De Gassart, A.; Guarda, G. T Cell Priming by Activated Nlrc5-Deficient Dendritic Cells Is Unaffected despite Partially Reduced MHC Class I Levels. J. Immunol. 2016, 196, 2939-2946. [CrossRef]

175. Dang, A.T.; Strietz, J.; Zenobi, A.; Khameneh, H.J.; Brandl, S.M.; Lozza, L.; Conradt, G.; Kaufmann, S.H.E.; Reith, W.; Kwee, I.; et al. NLRC5 promotes transcription of BTN3A1-3 genes and Vgamma9Vdelta2 T cell-mediated killing. iScience 2021, 24, 101900. [CrossRef] [PubMed]

176. Vantourout, P.; Hayday, A. Six-of-the-best: Unique contributions of gammadelta T cells to immunology. Nat. Rev. Immunol. 2013, 13, 88-100. [CrossRef]

177. Vantourout, P.; Laing, A.; Woodward, M.J.; Zlatareva, I.; Apolonia, L.; Jones, A.W.; Snijders, A.P.; Malim, M.H.; Hayday, A.C. Heteromeric interactions regulate butyrophilin (BTN) and BTN-like molecules governing gammadelta T cell biology. Proc. Natl. Acad. Sci. USA 2018, 115, 1039-1044. [CrossRef] [PubMed]

178. Arnett, H.A.; Viney, J.L. Immune modulation by butyrophilins. Nat. Rev. Immunol. 2014, 14, 559-569. [CrossRef]

179. Sarter, K.; Leimgruber, E.; Gobet, F.; Agrawal, V.; Dunand-Sauthier, I.; Barras, E.; Mastelic-Gavillet, B.; Kamath, A.; Fontannaz, P.; Guery, L.; et al. Btn2a2, a T cell immunomodulatory molecule coregulated with MHC class II genes. J. Exp. Med. 2016, 213, 177-187. [CrossRef]

180. Burr, M.L.; Sparbier, C.E.; Chan, K.L.; Chan, Y.C.; Kersbergen, A.; Lam, E.Y.N.; Azidis-Yates, E.; Vassiliadis, D.; Bell, C.C.; Gilan, O.; et al. An Evolutionarily Conserved Function of Polycomb Silences the MHC Class I Antigen Presentation Pathway and Enables Immune Evasion in Cancer. Cancer Cell 2019, 36, 385-401.e388. [CrossRef]

181. Kim, H.; Kim, H.; Feng, Y.; Li, Y.; Tamiya, H.; Tocci, S.; Ronai, Z.A. PRMT5 control of cGAS/STING and NLRC5 pathways defines melanoma response to antitumor immunity. Sci. Transl. Med. 2020, 12. [CrossRef] [PubMed]

182. Stopa, N.; Krebs, J.E.; Shechter, D. The PRMT5 arginine methyltransferase: Many roles in development, cancer and beyond. Cell Mol. Life Sci. 2015, 72, 2041-2059. [CrossRef]

183. Zebertavage, L.K.; Alice, A.; Crittenden, M.R.; Gough, M.J. Transcriptional Upregulation of NLRC5 by Radiation Drives STINGand Interferon-Independent MHC-I Expression on Cancer Cells and T Cell Cytotoxicity. Sci. Rep. 2020, 10, 7376. [CrossRef] [PubMed]

184. Wan, S.; Pestka, S.; Jubin, R.G.; Lyu, Y.L.; Tsai, Y.C.; Liu, L.F. Chemotherapeutics and radiation stimulate MHC class I expression through elevated interferon-beta signaling in breast cancer cells. PLoS ONE 2012, 7, e32542. [CrossRef]

185. Chung, S.A.; Nititham, J.; Elboudwarej, E.; Quach, H.L.; Taylor, K.E.; Barcellos, L.F.; Criswell, L.A. Genome-Wide Assessment of Differential DNA Methylation Associated with Autoantibody Production in Systemic Lupus Erythematosus. PLoS ONE 2015, 10, e0129813. [CrossRef]

186. Guo, X.M.; Liu, X.P.; Chang, G.B.; Xu, L.; Bi, Y.L.; Wang, H.Z.; Zhang, Y.; Zhu, P.F.; Wu, Y.; Chen, G.H. Characterization of the NLRC5 promoter in chicken: SNPs, regulatory elements and CpG islands. Anim. Genet. 2016, 47, 579-587. [CrossRef] [PubMed]

187. Agudo, J.; Park, E.S.; Rose, S.A.; Alibo, E.; Sweeney, R.; Dhainaut, M.; Kobayashi, K.S.; Sachidanandam, R.; Baccarini, A.; Merad, M.; et al. Quiescent Tissue Stem Cells Evade Immune Surveillance. Immunity 2018, 48, 271-285.e275. [CrossRef]

188. Suarez-Alvarez, B.; Rodriguez, R.M.; Calvanese, V.; Blanco-Gelaz, M.A.; Suhr, S.T.; Ortega, F.; Otero, J.; Cibelli, J.B.; Moore, H.; Fraga, M.F.; et al. Epigenetic mechanisms regulate MHC and antigen processing molecules in human embryonic and induced pluripotent stem cells. PLoS ONE 2010, 5, e10192. [CrossRef]

189. Schatton, T.; Schutte, U.; Frank, N.Y.; Zhan, Q.; Hoerning, A.; Robles, S.C.; Zhou, J.; Hodi, F.S.; Spagnoli, G.C.; Murphy, G.F.; et al. Modulation of T-cell activation by malignant melanoma initiating cells. Cancer Res. 2010, 70, 697-708. [CrossRef] [PubMed]

190. Di Tomaso, T.; Mazzoleni, S.; Wang, E.; Sovena, G.; Clavenna, D.; Franzin, A.; Mortini, P.; Ferrone, S.; Doglioni, C.; Marincola, F.M.; et al. Immunobiological characterization of cancer stem cells isolated from glioblastoma patients. Clin. Cancer Res. Off. J. Am. Assoc. Cancer Res. 2010, 16, 800-813. [CrossRef]

191. Maccalli, C.; Volonte, A.; Cimminiello, C.; Parmiani, G. Immunology of cancer stem cells in solid tumours. A review. Eur. J. Cancer 2014, 50, 649-655. [CrossRef]

192. Bruttel, V.S.; Wischhusen, J. Cancer stem cell immunology: Key to understanding tumorigenesis and tumor immune escape? Front. Immunol. 2014, 5, 360. [CrossRef] [PubMed] 
193. Sultan, M.; Coyle, K.M.; Vidovic, D.; Thomas, M.L.; Gujar, S.; Marcato, P. Hide-and-seek: The interplay between cancer stem cells and the immune system. Carcinogenesis 2017, 38, 107-118. [CrossRef]

194. Morrison, B.J.; Steel, J.C.; Morris, J.C. Reduction of MHC-I expression limits T-lymphocyte-mediated killing of Cancer-initiating cells. BMC Cancer 2018, 18, 469. [CrossRef] [PubMed]

195. Zhang, P.; Yu, C.; Yu, J.; Li, Z.; Lan, H.Y.; Zhou, Q. Arid2-IR promotes NF-kappaB-mediated renal inflammation by targeting NLRC5 transcription. Cell Mol. Life Sci. 2020. [CrossRef]

196. Zhou, Q.; Huang, X.R.; Yu, J.; Yu, X.; Lan, H.Y. Long Noncoding RNA Arid2-IR Is a Novel Therapeutic Target for Renal Inflammation. Mol. Ther. J. Am. Soc. Gene Ther. 2015, 23, 1034-1043. [CrossRef]

197. Zong, Z.; Song, Y.; Xue, Y.; Ruan, X.; Liu, X.; Yang, C.; Zheng, J.; Cao, S.; Li, Z.; Liu, Y. Knockdown of LncRNA SCAMP1 suppressed malignant biological behaviours of glioma cells via modulating miR-499a-5p/LMX1A/NLRC5 pathway. J. Cell Mol. Med. 2019, 23, 5048-5062. [CrossRef]

198. Muhlethaler-Mottet, A.; Otten, L.A.; Steimle, V.; Mach, B. Expression of MHC class II molecules in different cellular and functional compartments is controlled by differential usage of multiple promoters of the transactivator CIITA. EMBO J. 1997, 16, 2851-2860. [CrossRef]

199. LeibundGut-Landmann, S.; Waldburger, J.M.; Krawczyk, M.; Otten, L.A.; Suter, T.; Fontana, A.; Acha-Orbea, H.; Reith, W. Mini-review: Specificity and expression of CIITA, the master regulator of MHC class II genes. Eur. J. Immunol. 2004, 34, 1513-1525. [CrossRef] [PubMed]

200. Periyasamy, P.; Thangaraj, A.; Bendi, V.S.; Buch, S. HIV-1 Tat-mediated microglial inflammation involves a novel miRNA-34aNLRC5-NFkappaB signaling axis. Brain Behav. Immun. 2019, 80, 227-237. [CrossRef] [PubMed]

201. Li, J.; Yu, L.; Shen, Z.; Li, Y.; Chen, B.; Wei, W.; Chen, X.; Wang, Q.; Tong, F.; Lou, H.; et al. miR-34a and its novel target, NLRC5, are associated with HPV16 persistence. Infect. Genet. Evol. 2016, 44, 293-299. [CrossRef]

202. Zong, Y.; Zhang, Y.; Hou, D.; Xu, J.; Cui, F.; Qin, Y.; Sun, X. The lncRNA XIST promotes the progression of breast cancer by sponging miR-125b-5p to modulate NLRC5. Am. J. Transl. Res. 2020, 12, 3501-3511.

203. Rodino, K.G.; Adcox, H.E.; Martin, R.K.; Patel, V.; Conrad, D.H.; Carlyon, J.A. The Obligate Intracellular Bacterium Orientia tsutsugamushi Targets NLRC5 To Modulate the Major Histocompatibility Complex Class I Pathway. Infect. Immun. $2019,87$. [CrossRef]

204. Meng, Q.; Cai, C.; Sun, T.; Wang, Q.; Xie, W.; Wang, R.; Cui, J. Reversible ubiquitination shapes NLRC5 function and modulates NF-kappaB activation switch. J. Cell Biol. 2015, 211, 1025-1040. [CrossRef] [PubMed]

205. Hu, Y. A feedforward loop of NLRC5 (de)ubiquitination keeps IKK-NF-kappaB in check. J. Cell Biol. 2015, 211, 941-943. [CrossRef] [PubMed]

206. Xia, Y.; Shen, S.; Verma, I.M. NF-kappaB, an active player in human cancers. Cancer Immunol. Res. 2014, 2, 823-830. [CrossRef]

207. Taniguchi, K.; Karin, M. NF-kappaB, inflammation, immunity and cancer: Coming of age. Nat. Rev. Immunol. 2018, 18, 309-324. [CrossRef]

208. Dersh, D.; Phelan, J.D.; Gumina, M.E.; Wang, B.; Arbuckle, J.H.; Holly, J.; Kishton, R.J.; Markowitz, T.E.; Seedhom, M.O.; Fridlyand, N.; et al. Genome-wide Screens Identify Lineage- and Tumor-Specific Genes Modulating MHC-I- and MHC-IIRestricted Immunosurveillance of Human Lymphomas. Immunity 2020. [CrossRef]

209. Bhavsar, A.P.; Brown, N.F.; Stoepel, J.; Wiermer, M.; Martin, D.D.; Hsu, K.J.; Imami, K.; Ross, C.J.; Hayden, M.R.; Foster, L.J.; et al The Salmonella type III effector SspH2 specifically exploits the NLR co-chaperone activity of SGT1 to subvert immunity. PLoS Pathog. 2013, 9, e1003518. [CrossRef]

210. Mayor, A.; Martinon, F.; De Smedt, T.; Petrilli, V.; Tschopp, J. A crucial function of SGT1 and HSP90 in inflammasome activity links mammalian and plant innate immune responses. Nat. Immunol. 2007, 8, 497-503. [CrossRef]

211. Kitagawa, K.; Skowyra, D.; Elledge, S.J.; Harper, J.W.; Hieter, P. SGT1 encodes an essential component of the yeast kinetochore assembly pathway and a novel subunit of the SCF ubiquitin ligase complex. Mol. Cell 1999, 4, 21-33. [CrossRef]

212. Willhoft, O.; Kerr, R.; Patel, D.; Zhang, W.; Al-Jassar, C.; Daviter, T.; Millson, S.H.; Thalassinos, K.; Vaughan, C.K. The crystal structure of the Sgt1-Skp1 complex: The link between Hsp90 and both SCF E3 ubiquitin ligases and kinetochores. Sci. Rep. 2017, 7, 41626. [CrossRef] [PubMed]

213. Overwijk, W.W.; Restifo, N.P. B16 as a mouse model for human melanoma. Curr. Protoc. Immunol. 2001, 20. [CrossRef]

214. Kalbasi, A.; Tariveranmoshabad, M.; Hakimi, K.; Kremer, S.; Campbell, K.M.; Funes, J.M.; Vega-Crespo, A.; Parisi, G.; Champekar, A.; Nguyen, C.; et al. Uncoupling interferon signaling and antigen presentation to overcome immunotherapy resistance due to JAK1 loss in melanoma. Sci. Transl. Med. 2020, 12. [CrossRef] [PubMed]

215. Peng, Y.Y.; He, Y.H.; Chen, C.; Xu, T.; Li, L.; Ni, M.M.; Meng, X.M.; Huang, C.; Li, J. NLRC5 regulates cell proliferation, migration and invasion in hepatocellular carcinoma by targeting the Wnt/beta-catenin signaling pathway. Cancer Lett. 2016, 376, 10-21. [CrossRef]

216. Wang, Q.; Ding, H.; He, Y.; Li, X.; Cheng, Y.; Xu, Q.; Yang, Y.; Liao, G.; Meng, X.; Huang, C.; et al. NLRC5 mediates cell proliferation, migration, and invasion by regulating the Wnt/beta-catenin signalling pathway in clear cell renal cell carcinoma. Cancer Lett. 2019, 444, 9-19. [CrossRef]

217. He, Y.H.; Li, M.F.; Zhang, X.Y.; Meng, X.M.; Huang, C.; Li, J. NLRC5 promotes cell proliferation via regulating the AKT/VEGF-A signaling pathway in hepatocellular carcinoma. Toxicology 2016, 359-360, 47-57. [CrossRef] 
218. Fan, Y.; Dong, Z.; Shi, Y.; Sun, S.; Wei, B.; Zhan, L. NLRC5 promotes cell migration and invasion by activating the PI3K/AKT signaling pathway in endometrial cancer. J. Int. Med. Res. 2020, 48, 300060520925352. [CrossRef] [PubMed]

219. Hu, X.; Wang, M.; Cao, L.; Cong, L.; Gao, Y.; Lu, J.; Feng, J.; Shen, B.; Liu, D. miR-4319 Suppresses the Growth of Esophageal Squamous Cell Carcinoma Via Targeting NLRC5. Curr. Mol. Pharm. 2020, 13, 144-149. [CrossRef]

220. Ozcan, M.; Janikovits, J.; von Knebel Doeberitz, M.; Kloor, M. Complex pattern of immune evasion in MSI colorectal cancer. Oncoimmunology 2018, 7, e1445453. [CrossRef]

221. Alimonti, J.; Zhang, Q.J.; Gabathuler, R.; Reid, G.; Chen, S.S.; Jefferies, W.A. TAP expression provides a general method for improving the recognition of malignant cells in vivo. Nat. Biotechnol. 2000, 18, 515-520. [CrossRef]

222. Lou, Y.; Basha, G.; Seipp, R.P.; Cai, B.; Chen, S.S.; Moise, A.R.; Jeffries, A.P.; Gopaul, R.S.; Vitalis, T.Z.; Jefferies, W.A. Combining the antigen processing components TAP and Tapasin elicits enhanced tumor-free survival. Clin. Cancer Res. Off. J. Am. Assoc. Cancer Res. 2008, 14, 1494-1501. [CrossRef] [PubMed]

223. Li, X.L.; Zhang, D.; Knight, D.; Odaka, Y.; Glass, J.; Mathis, J.M.; Zhang, Q.J. Priming of immune responses against transporter associated with antigen processing (TAP)-deficient tumours: Tumour direct priming. Immunology 2009, 128, 420-428. [CrossRef] [PubMed]

224. Del Campo, A.B.; Aptsiauri, N.; Mendez, R.; Zinchenko, S.; Vales, A.; Paschen, A.; Ward, S.; Ruiz-Cabello, F.; GonzalezAseguinolaza, G.; Garrido, F. Efficient recovery of HLA class I expression in human tumor cells after beta2-microglobulin gene transfer using adenoviral vector: Implications for cancer immunotherapy. Scand. J. Immunol. 2009, 70, 125-135. [CrossRef] [PubMed]

225. Bellucci, R.; Martin, A.; Bommarito, D.; Wang, K.; Hansen, S.H.; Freeman, G.J.; Ritz, J. Interferon-gamma-induced activation of JAK1 and JAK2 suppresses tumor cell susceptibility to NK cells through upregulation of PD-L1 expression. Oncoimmunology 2015, 4, e1008824. [CrossRef]

226. Benci, J.L.; Xu, B.; Qiu, Y.; Wu, T.J.; Dada, H.; Twyman-Saint Victor, C.; Cucolo, L.; Lee, D.S.M.; Pauken, K.E.; Huang, A.C.; et al. Tumor Interferon Signaling Regulates a Multigenic Resistance Program to Immune Checkpoint Blockade. Cell 2016, 167, 1540-1554.e1512. [CrossRef]

227. Garcia-Diaz, A.; Shin, D.S.; Moreno, B.H.; Saco, J.; Escuin-Ordinas, H.; Rodriguez, G.A.; Zaretsky, J.M.; Sun, L.; Hugo, W.; Wang, X.; et al. Interferon Receptor Signaling Pathways Regulating PD-L1 and PD-L2 Expression. Cell Rep. 2017, 19, 1189-1201. [CrossRef] [PubMed]

228. Ivashkiv, L.B. IFNgamma: Signalling, epigenetics and roles in immunity, metabolism, disease and cancer immunotherapy. Nat. Rev. Immunol. 2018, 18, 545-558. [CrossRef]

229. McGray, A.J.; Hallett, R.; Bernard, D.; Swift, S.L.; Zhu, Z.; Teoderascu, F.; Vanseggelen, H.; Hassell, J.A.; Hurwitz, A.A.; Wan, Y.; et al. Immunotherapy-induced CD8+ T cells instigate immune suppression in the tumor. Mol. Ther. J. Am. Soc. Gene Ther. 2014, 22, 206-218. [CrossRef]

230. Castro, F.; Cardoso, A.P.; Goncalves, R.M.; Serre, K.; Oliveira, M.J. Interferon-Gamma at the Crossroads of Tumor Immune Surveillance or Evasion. Front. Immunol. 2018, 9, 847. [CrossRef]

231. Zaidi, M.R. The Interferon-Gamma Paradox in Cancer. J. Interferon Cytokine Res. 2019, 39, 30-38. [CrossRef] [PubMed]

232. Qiao, Y.; Kang, K.; Giannopoulou, E.; Fang, C.; Ivashkiv, L.B. IFN-gamma Induces Histone 3 Lysine 27 Trimethylation in a Small Subset of Promoters to Stably Silence Gene Expression in Human Macrophages. Cell Rep. 2016, 16, 3121-3129. [CrossRef]

233. Ivashkiv, L.B.; Donlin, L.T. Regulation of type I interferon responses. Nat. Rev. Immunol. 2014, 14, 36-49. [CrossRef]

234. Antonczyk, A.; Krist, B.; Sajek, M.; Michalska, A.; Piaszyk-Borychowska, A.; Plens-Galaska, M.; Wesoly, J.; Bluyssen, H.A.R. Direct Inhibition of IRF-Dependent Transcriptional Regulatory Mechanisms Associated with Disease. Front. Immunol. 2019, 10, 1176. [CrossRef] [PubMed]

235. Stark, G.R.; Kerr, I.M.; Williams, B.R.; Silverman, R.H.; Schreiber, R.D. How cells respond to interferons. Annu. Rev. Biochem. 1998, 67, 227-264. [CrossRef] [PubMed]

236. Musella, M.; Manic, G.; De Maria, R.; Vitale, I.; Sistigu, A. Type-I-interferons in infection and cancer: Unanticipated dynamics with therapeutic implications. Oncoimmunology 2017, 6, e1314424. [CrossRef] [PubMed]

237. Gessani, S.; Conti, L.; Del Corno, M.; Belardelli, F. Type I interferons as regulators of human antigen presenting cell functions. Toxins 2014, 6, 1696-1723. [CrossRef]

238. Budhwani, M.; Mazzieri, R.; Dolcetti, R. Plasticity of Type I Interferon-Mediated Responses in Cancer Therapy: From Anti-tumor Immunity to Resistance. Front. Oncol. 2018, 8, 322. [CrossRef]

239. Sistigu, A.; Yamazaki, T.; Vacchelli, E.; Chaba, K.; Enot, D.P.; Adam, J.; Vitale, I.; Goubar, A.; Baracco, E.E.; Remedios, C.; et al. Cancer cell-autonomous contribution of type I interferon signaling to the efficacy of chemotherapy. Nat. Med. 2014, 20, 1301-1309. [CrossRef]

240. Wang, X.; Schoenhals, J.E.; Li, A.; Valdecanas, D.R.; Ye, H.; Zang, F.; Tang, C.; Tang, M.; Liu, C.G.; Liu, X.; et al. Suppression of Type I IFN Signaling in Tumors Mediates Resistance to Anti-PD-1 Treatment That Can Be Overcome by Radiotherapy. Cancer Res. 2017, 77, 839-850. [CrossRef]

241. Xi, S.; Dyer, K.F.; Kimak, M.; Zhang, Q.; Gooding, W.E.; Chaillet, J.R.; Chai, R.L.; Ferrell, R.E.; Zamboni, B.; Hunt, J.; et al. Decreased STAT1 expression by promoter methylation in squamous cell carcinogenesis. J. Natl. Cancer Inst. 2006, 98, 181-189. [CrossRef] [PubMed] 
242. Komyod, W.; Bohm, M.; Metze, D.; Heinrich, P.C.; Behrmann, I. Constitutive suppressor of cytokine signaling 3 expression confers a growth advantage to a human melanoma cell line. Mol. Cancer Res. 2007, 5, 271-281. [CrossRef]

243. Kaufman, H.L.; Kohlhapp, F.J.; Zloza, A. Oncolytic viruses: A new class of immunotherapy drugs. Nat. Rev. Drug Discov. 2015, 14, 642-662. [CrossRef] [PubMed]

244. Twumasi-Boateng, K.; Pettigrew, J.L.; Kwok, Y.Y.E.; Bell, J.C.; Nelson, B.H. Oncolytic viruses as engineering platforms for combination immunotherapy. Nat. Rev. Cancer 2018, 18, 419-432. [CrossRef] [PubMed]

245. Martinez-Quintanilla, J.; Seah, I.; Chua, M.; Shah, K. Oncolytic viruses: Overcoming translational challenges. J. Clin. Investig. 2019, 129, 1407-1418. [CrossRef] [PubMed]

246. Widschwendter, M.; Jones, A.; Evans, I.; Reisel, D.; Dillner, J.; Sundstrom, K.; Steyerberg, E.W.; Vergouwe, Y.; Wegwarth, O.; Rebitschek, F.G.; et al. Epigenome-based cancer risk prediction: Rationale, opportunities and challenges. Nat. Rev. Clin. Oncol. 2018, 15, 292-309. [CrossRef]

247. Ahuja, N.; Sharma, A.R.; Baylin, S.B. Epigenetic Therapeutics: A New Weapon in the War Against Cancer. Annu. Rev. Med. 2016, 67, 73-89. [CrossRef] [PubMed]

248. Bates, S.E. Epigenetic Therapies for Cancer. N. Engl. J. Med. 2020, 383, 650-663. [CrossRef]

249. Kortenhorst, M.S.; Wissing, M.D.; Rodriguez, R.; Kachhap, S.K.; Jans, J.J.; Van der Groep, P.; Verheul, H.M.; Gupta, A.; Aiyetan, P.O.; van der Wall, E.; et al. Analysis of the genomic response of human prostate cancer cells to histone deacetylase inhibitors. Epigenetics 2013, 8, 907-920. [CrossRef]

250. Cheng, Y.; He, C.; Wang, M.; Ma, X.; Mo, F.; Yang, S.; Han, J.; Wei, X. Targeting epigenetic regulators for cancer therapy: Mechanisms and advances in clinical trials. Signal. Transduct Target. Ther. 2019, 4, 62. [CrossRef]

251. Kungulovski, G.; Jeltsch, A. Epigenome Editing: State of the Art, Concepts, and Perspectives. Trends Genet. 2016, 32, 101-113. [CrossRef] [PubMed]

252. Nebbioso, A.; Tambaro, F.P.; Dell'Aversana, C.; Altucci, L. Cancer epigenetics: Moving forward. PLoS Genet. 2018, 14, e1007362. [CrossRef]

253. Romero, I.; Martinez, M.; Garrido, C.; Collado, A.; Algarra, I.; Garrido, F.; Garcia-Lora, A.M. The tumour suppressor Fhit positively regulates MHC class I expression on cancer cells. J. Pathol. 2012, 227, 367-379. [CrossRef] [PubMed]

254. Pulido, M.; Chamorro, V.; Romero, I.; Algarra, I.A.S.M.; Collado, A.; Garrido, F.; Garcia-Lora, A.M. Restoration of MHC-I on Tumor Cells by Fhit Transfection Promotes Immune Rejection and Acts as an Individualized Immunotherapeutic Vaccine. Cancers 2020, 12, 1563. [CrossRef]

255. Joly, E.; Hudrisier, D. What is trogocytosis and what is its purpose? Nat. Immunol. 2003, 4, 815. [CrossRef] [PubMed]

256. Wakim, L.M.; Bevan, M.J. Cross-dressed dendritic cells drive memory CD8+ T-cell activation after viral infection. Nature 2011, 471, 629-632. [CrossRef] [PubMed]

257. Pyo, C.W.; Williams, L.M.; Moore, Y.; Hyodo, H.; Li, S.S.; Zhao, L.P.; Sageshima, N.; Ishitani, A.; Geraghty, D.E. HLA-E, HLA-F, and HLA-G polymorphism: Genomic sequence defines haplotype structure and variation spanning the nonclassical class I genes. Immunogenetics 2006, 58, 241-251. [CrossRef]

258. Goodall, K.J.; Nguyen, A.; Sullivan, L.C.; Andrews, D.M. The expanding role of murine class Ib MHC in the development and activation of Natural Killer cells. Mol. Immunol. 2019, 115, 31-38. [CrossRef]

259. Moser, J.M.; Gibbs, J.; Jensen, P.E.; Lukacher, A.E. CD94-NKG2A receptors regulate antiviral CD8(+) T cell responses. Nat. Immunol. 2002, 3, 189-195. [CrossRef]

260. Vance, R.E.; Jamieson, A.M.; Cado, D.; Raulet, D.H. Implications of CD94 deficiency and monoallelic NKG2A expression for natural killer cell development and repertoire formation. Proc. Natl. Acad. Sci. USA 2002, 99, 868-873. [CrossRef]

261. Pegram, H.J.; Andrews, D.M.; Smyth, M.J.; Darcy, P.K.; Kershaw, M.H. Activating and inhibitory receptors of natural killer cells. Immunol. Cell Biol. 2011, 89, 216-224. [CrossRef]

262. Paul, S.; Lal, G. The Molecular Mechanism of Natural Killer Cells Function and Its Importance in Cancer Immunotherapy. Front. Immunol. 2017, 8, 1124. [CrossRef] [PubMed]

263. Abd Hamid, M.; Wang, R.Z.; Yao, X.; Fan, P.; Li, X.; Chang, X.M.; Feng, Y.; Jones, S.; Maldonado-Perez, D.; Waugh, C.; et al Enriched HLA-E and CD94/NKG2A Interaction Limits Antitumor CD8(+) Tumor-Infiltrating T Lymphocyte Responses. Cancer Immunol. Res. 2019, 7, 1293-1306. [CrossRef]

264. Kamiya, T.; Seow, S.V.; Wong, D.; Robinson, M.; Campana, D. Blocking expression of inhibitory receptor NKG2A overcomes tumor resistance to NK cells. J. Clin. Investig. 2019, 129, 2094-2106. [CrossRef]

265. Ottenhoff, T.H.M.; Joosten, S.A. Mobilizing unconventional T cells. Science 2019, 366, 302-303. [CrossRef]

266. Wiendl, H.; Mitsdoerffer, M.; Hofmeister, V.; Wischhusen, J.; Bornemann, A.; Meyermann, R.; Weiss, E.H.; Melms, A.; Weller, M. A functional role of HLA-G expression in human gliomas: An alternative strategy of immune escape. J. Immunol. 2002, 168, 4772-4780. [CrossRef] [PubMed]

267. Rouas-Freiss, N.; Moreau, P.; Ferrone, S.; Carosella, E.D. HLA-G proteins in cancer: Do they provide tumor cells with an escape mechanism? Cancer Res. 2005, 65, 10139-10144. [CrossRef]

268. Rousseau, P.; Masternak, K.; Krawczyk, M.; Reith, W.; Dausset, J.; Carosella, E.D.; Moreau, P. In vivo, RFX5 binds differently to the human leucocyte antigen-E, $-\mathrm{F}$, and $-\mathrm{G}$ gene promoters and participates in HLA class I protein expression in a cell type-dependent manner. Immunology 2004, 111, 53-65. [CrossRef] [PubMed] 
269. Jacquelot, N.; Yamazaki, T.; Roberti, M.P.; Duong, C.P.M.; Andrews, M.C.; Verlingue, L.; Ferrere, G.; Becharef, S.; Vetizou, M.; Daillere, R.; et al. Sustained Type I interferon signaling as a mechanism of resistance to PD-1 blockade. Cell Res. 2019, $29,846-861$. [CrossRef]

270. Pardi, N.; Hogan, M.J.; Porter, F.W.; Weissman, D. mRNA vaccines-A new era in vaccinology. Nat. Rev. Drug Discov. 2018, 17, 261-279. [CrossRef]

271. Van Lint, S.; Renmans, D.; Broos, K.; Goethals, L.; Maenhout, S.; Benteyn, D.; Goyvaerts, C.; Du Four, S.; Van der Jeught, K.; Bialkowski, L.; et al. Intratumoral Delivery of TriMix mRNA Results in T-cell Activation by Cross-Presenting Dendritic Cells. Cancer Immunol. Res. 2016, 4, 146-156. [CrossRef]

272. Van der Jeught, K.; Van Lint, S.; Thielemans, K.; Breckpot, K. Intratumoral delivery of mRNA: Overcoming obstacles for effective immunotherapy. Oncoimmunology 2015, 4, e1005504. [CrossRef] [PubMed]

273. Van der Jeught, K.; Joe, P.T.; Bialkowski, L.; Heirman, C.; Daszkiewicz, L.; Liechtenstein, T.; Escors, D.; Thielemans, K.; Breckpot, $\mathrm{K}$. Intratumoral administration of mRNA encoding a fusokine consisting of IFN-beta and the ectodomain of the TGF-beta receptor II potentiates antitumor immunity. Oncotarget 2014, 5, 10100-10113. [CrossRef]

274. Neerincx, A.; Jakobshagen, K.; Utermohlen, O.; Buning, H.; Steimle, V.; Kufer, T.A. The N-terminal domain of NLRC5 confers transcriptional activity for MHC class I and II gene expression. J. Immunol. 2014, 193, 3090-3100. [CrossRef] [PubMed]

275. Robbins, P.F.; Lu, Y.C.; El-Gamil, M.; Li, Y.F.; Gross, C.; Gartner, J.; Lin, J.C.; Teer, J.K.; Cliften, P.; Tycksen, E.; et al. Mining exomic sequencing data to identify mutated antigens recognized by adoptively transferred tumor-reactive T cells. Nat. Med. 2013, 19, 747-752. [CrossRef] [PubMed]

276. Sharma, P.; Allison, J.P. Immune checkpoint targeting in cancer therapy: Toward combination strategies with curative potential. Cell 2015, 161, 205-214. [CrossRef]

277. Topalian, S.L.; Drake, C.G.; Pardoll, D.M. Immune checkpoint blockade: A common denominator approach to cancer therapy. Cancer Cell 2015, 27, 450-461. [CrossRef] [PubMed]

278. Schadendorf, D.; Hodi, F.S.; Robert, C.; Weber, J.S.; Margolin, K.; Hamid, O.; Patt, D.; Chen, T.T.; Berman, D.M.; Wolchok, J.D. Pooled Analysis of Long-Term Survival Data from Phase II and Phase III Trials of Ipilimumab in Unresectable or Metastatic Melanoma. J. Clin. Oncol. 2015, 33, 1889-1894. [CrossRef]

279. Sivan, A.; Corrales, L.; Hubert, N.; Williams, J.B.; Aquino-Michaels, K.; Earley, Z.M.; Benyamin, F.W.; Lei, Y.M.; Jabri, B.; Alegre, M.L.; et al. Commensal Bifidobacterium promotes antitumor immunity and facilitates anti-PD-L1 efficacy. Science 2015, 350, 1084-1089. [CrossRef]

280. Vetizou, M.; Pitt, J.M.; Daillere, R.; Lepage, P.; Waldschmitt, N.; Flament, C.; Rusakiewicz, S.; Routy, B.; Roberti, M.P.; Duong, C.P.; et al. Anticancer immunotherapy by CTLA-4 blockade relies on the gut microbiota. Science 2015, 350, 1079-1084. [CrossRef]

281. Pitt, J.M.; Vetizou, M.; Daillere, R.; Roberti, M.P.; Yamazaki, T.; Routy, B.; Lepage, P.; Boneca, I.G.; Chamaillard, M.; Kroemer, G.; et al. Resistance Mechanisms to Immune-Checkpoint Blockade in Cancer: Tumor-Intrinsic and -Extrinsic Factors. Immunity 2016, 44, 1255-1269. [CrossRef]

282. Topalian, S.L.; Taube, J.M.; Anders, R.A.; Pardoll, D.M. Mechanism-driven biomarkers to guide immune checkpoint blockade in cancer therapy. Nat. Rev. Cancer 2016, 16, 275-287. [CrossRef]

283. Yuan, J.; Hegde, P.S.; Clynes, R.; Foukas, P.G.; Harari, A.; Kleen, T.O.; Kvistborg, P.; Maccalli, C.; Maecker, H.T.; Page, D.B.; et al. Novel technologies and emerging biomarkers for personalized cancer immunotherapy. J. Immunother. Cancer $2016,4,3$. [CrossRef] [PubMed]

284. Charoentong, P.; Finotello, F.; Angelova, M.; Mayer, C.; Efremova, M.; Rieder, D.; Hackl, H.; Trajanoski, Z. Pan-cancer Immunogenomic Analyses Reveal Genotype-Immunophenotype Relationships and Predictors of Response to Checkpoint Blockade. Cell Rep. 2017, 18, 248-262. [CrossRef]

285. Ganesan, S.; Mehnert, J. Biomarkers for Response to Immune Checkpoint Blockade. Annu. Rev. Cancer Biol. 2020, 4, 331-351. [CrossRef]

286. Lizee, G.; Overwijk, W.W.; Radvanyi, L.; Gao, J.; Sharma, P.; Hwu, P. Harnessing the power of the immune system to target cancer. Annu. Rev. Med. 2013, 64, 71-90. [CrossRef] [PubMed]

287. John, L.B.; Kershaw, M.H.; Darcy, P.K. Blockade of PD-1 immunosuppression boosts CAR T-cell therapy. Oncoimmunology 2013, 2, e26286. [CrossRef] [PubMed]

288. Twyman-Saint Victor, C.; Rech, A.J.; Maity, A.; Rengan, R.; Pauken, K.E.; Stelekati, E.; Benci, J.L.; Xu, B.; Dada, H.; Odorizzi, P.M.; et al. Radiation and dual checkpoint blockade activate non-redundant immune mechanisms in cancer. Nature 2015, 520, 373-377. [CrossRef]

289. Smyth, M.J.; Ngiow, S.F.; Ribas, A.; Teng, M.W. Combination cancer immunotherapies tailored to the tumour microenvironment. Nat. Rev. Clin. Oncol. 2016, 13, 143-158. [CrossRef] [PubMed]

290. Howat, W.J.; Lewis, A.; Jones, P.; Kampf, C.; Ponten, F.; van der Loos, C.M.; Gray, N.; Womack, C.; Warford, A. Antibody validation of immunohistochemistry for biomarker discovery: Recommendations of a consortium of academic and pharmaceutical based histopathology researchers. Methods 2014, 70, 34-38. [CrossRef]

291. O'Hurley, G.; Sjostedt, E.; Rahman, A.; Li, B.; Kampf, C.; Ponten, F.; Gallagher, W.M.; Lindskog, C. Garbage in, garbage out: A critical evaluation of strategies used for validation of immunohistochemical biomarkers. Mol. Oncol. 2014, 8, 783-798. [CrossRef] [PubMed] 
292. Li, X.; Guo, F.; Liu, Y.; Chen, H.J.; Wen, F.; Zou, B.; Li, D.; Qin, Q.; Liu, X.; Shen, Y.; et al. NLRC5 expression in tumors and its role as a negative prognostic indicator in stage III non-small-cell lung cancer patients. Oncol. Lett. 2015, 10, 1533-1540. [CrossRef] [PubMed]

293. Li, Y.; Zhang, M.; Zheng, X. High Expression of NLRC5 Is Associated with Prognosis of Gastric Cancer. Open Med. (Wars) 2018, 13, 443-449. [CrossRef] [PubMed] 